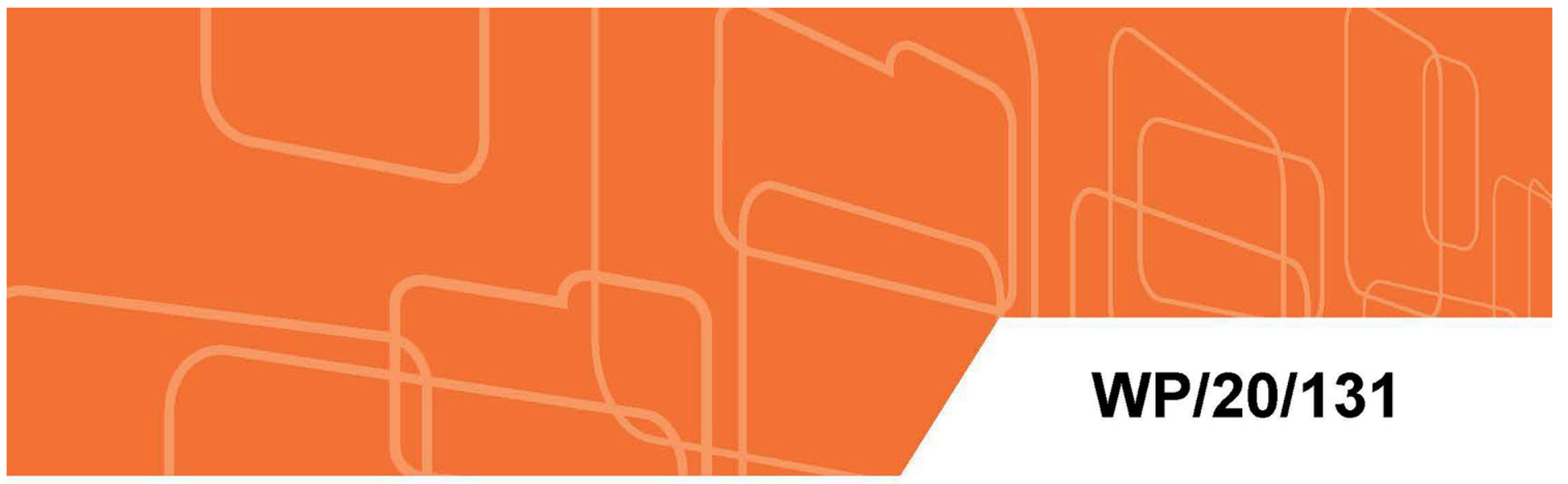

IMF Working Paper

\title{
International Trade and Corporate Market Power
}

by Jesus Gonzalez-Garcia and Yuanchen Yang

IMF Working Papers describe research in progress by the author(s) and are published to elicit comments and to encourage debate. The views expressed in IMF Working Papers are those of the author(s) and do not necessarily represent the views of the IMF, its Executive Board, or IMF management. 


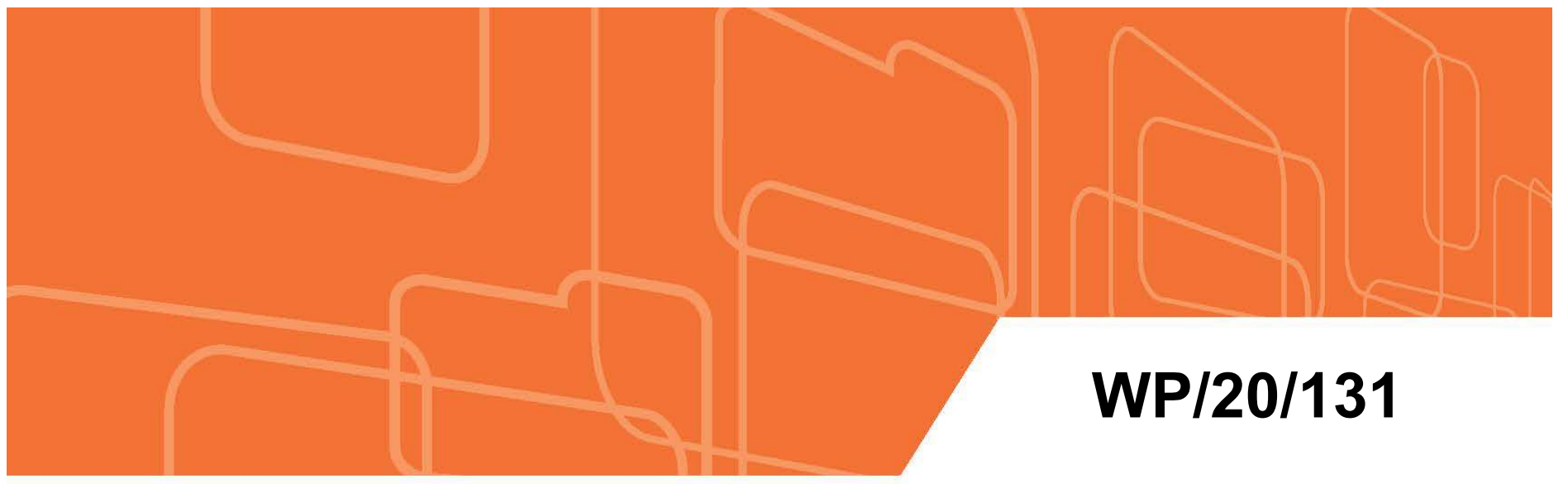

\section{IMF Working Paper}

\section{International Trade and Corporate Market Power}

by Jesus Gonzalez-Garcia and Yuanchen Yang

IMF Working Papers describe research in progress by the author(s) and are published to elicit comments and to encourage debate. The views expressed in IMF Working Papers are those of the author(s) and do not necessarily represent the views of the IMF, its Executive Board, or IMF management.

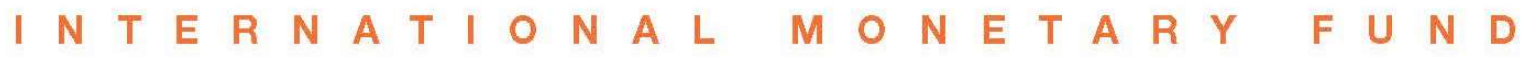




\title{
IMF Working Paper
}

\author{
African Department \\ International Trade and Corporate Market Power* \\ Prepared by Jesus Gonzalez-Garcia and Yuanchen Yang \\ Authorized for distribution by Papa N'Diaye
}

July 2020

\begin{abstract}
IMF Working Papers describe research in progress by the author(s) and are published to elicit comments and to encourage debate. The views expressed in IMF Working Papers are those of the author(s) and do not necessarily represent the views of the IMF, its Executive Board, or IMF management.
\end{abstract}

\begin{abstract}
This paper examines the effect of international trade on corporate market power in emerging market economies and developing countries, with a special focus on sub-Saharan Africa. The analysis is based on a large firm-level dataset, tariff data by sector and agreggate indicators of international trade for the period 2000-17. Greater trade liberalization and trade integration are associated with significant declines in market power, with the effect being more pronounced for firms in the manufacturing and ICT sectors, private sector firms, and firms with higher initial markups. Firms in sub-Saharan Africa tend to experience signficantly lower markups after allowing greater trade integration. The effects of trade liberalization on market power materializes over time, and there are significant complementarities between trade reforms and real sector reforms.

JEL Classification Numbers: D40, F10, P11.
\end{abstract}

Keywords: competition, developing countries, emerging markets, international trade, market power, markups, trade liberalization.

Author's E-Mail Address: Jesus Gonzalez-Garcia: igonzalezgarcia@imf.org; Yuanchen Yang: yangych.16@pbcsf.tsinghua.edu.cn.

\footnotetext{
* The research underlying this paper was initiated in the context of the preparation of IMF's October 2019 Regional Economic Outlook for Sub-Saharan Africa. We would like to thank Mahvash Saeed Qureshi for useful suggestions, as well as colleagues in the African Department for their comments. The usual disclaimer applies.
} 


\section{Contents}

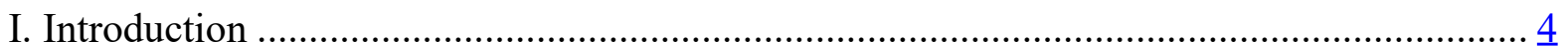

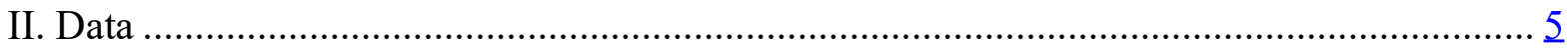

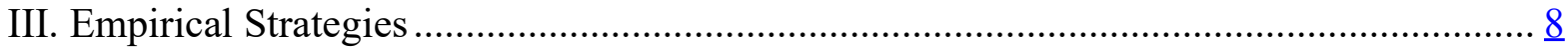

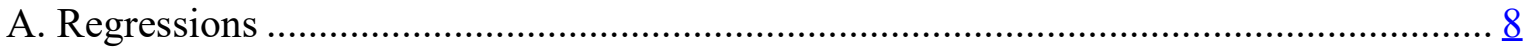

B. Impulse-Responses ..................................................................................... 9

C. Complementarity of Different Reforms ............................................................ 9

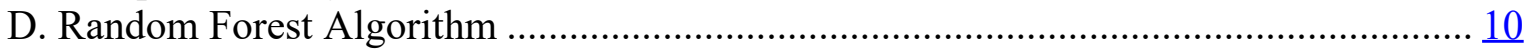

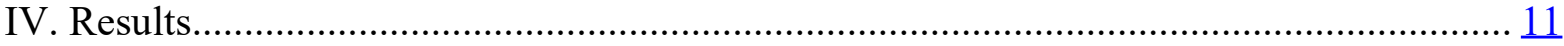

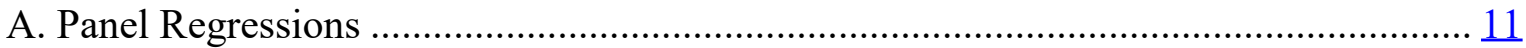

B. Dynamic Effects of Reforms............................................................................ 13

C. Trade Liberalization and Firm and Sector Characteristics....................................... 13

D. Trade Integration and Market Power …............................................................ 14

E. Differentiated Effects of Concurrent Structural Reforms ….................................... 15

V. Robustness Checks........................................................................................ 16

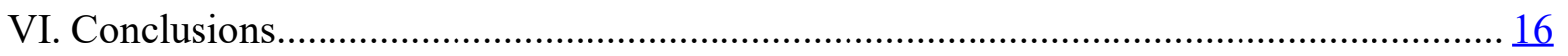

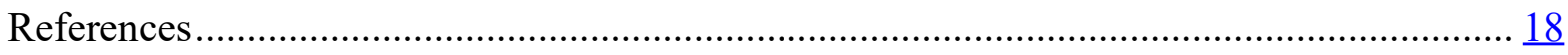

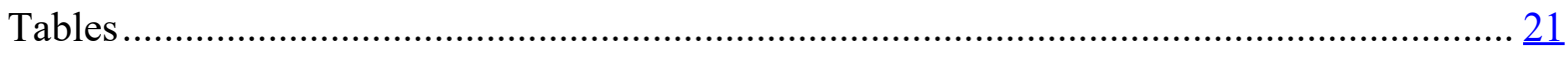

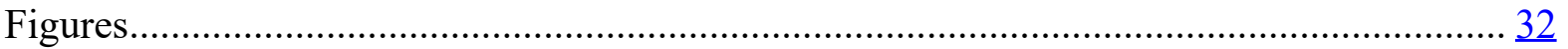




\section{INTRODUCTION}

In recent decades, many emerging market and developing economies have liberalized international trade in order to spur gains in productivity and efficiency. One of the main channels by which trade liberalization improves productive capacity is by unleashing firm dynamics that foster better allocation of resources (see for instance UNCTAD, 2009; Chen and Scott, 2009 and Konings et al., 2001). These dynamics benefit not only firms and final consumers but also make the economy more able to compete in international markets.

A reduction in international trade tariffs can affect domestic firms in various ways: greater head-on competition from foreign goods and services forces firms to upgrade their methods and become more efficient (Brandt et al., 2017) and less productive firms are forced to exit; increased availability of intermediate goods reduces firms' production costs (Kasahara and Rodriguez, 2008); and access to international markets allow export oriented firms to achieve economies of scale. Another important reason why several emerging market and developing economies have embarked in trade liberalization is benefiting from their comparative advantages, which also involves reallocating resources to more productive firms and sectors (Edwards, 1998; Amiti and Konings, 2007; Fernandes, 2007; Goldberg et al., 2010; Khandelwal and Topalova, 2011; Lileeva and Trefler, 2011), and from technology transmission and spillovers (Teshima, 2009; Bustos, 2011; Boler et al., 2015; Bloom and Van Reenen, 2016).

This paper evaluates the effects of international trade on domestic market power using a large firm-level dataset covering 83 emerging market economies and developing countries for the period 2000-2017 and different indicators of international trade liberalization and trade integration with the aim to contribute to the existing literature in the following ways. First, it is focused on competition and market power in emerging economies and developing countries using firm level data, in contrast with the existing literature that focuses on advanced economies, and within that group special attention is given to one of the largest but less studied regions: sub-Saharan Africa. Second, the analysis incorporates detailed tariff data by sector that allows to better estimate the effects of tariff changes on domestic market power. Third, in addition to different panel data models, this paper employs the methodology of random forest algorithm to distinguish the magnituge of the influence of different structural reforms on domestic market power and identify the relative importance and interactions between different reforms.

The macroeconomic environments in economies undertaking trade reforms could vary significantly and affect market power in a way that trade liberalization indicators alone cannot capture. We account for this by controlling for non-tariff trade barriers, an array of macro-level factors including for instance the income level, output growth, institutional quality and economic uncertainty, and also other structural reforms that may enhance or limit the relationship of international trade with domestic competition (Christiansen et al., 2009; Spilimbergo et al., 2009; Bordon et al., 2016; Dabla-Norris et al., 2016; ElFayoumi et al., 2018; Kouamé and Tapsoba, 2018). We find that institutional characteristics and concurrent reforms do have an effect on domestic market power, represented by firm level markups, but trade reform remains a salient factor to shape the market power of firms. 
As Rodríguez and Rodrik (2000) suggest, the search for an empirical relationship between trade liberalization and economic growth and development should bring microeconomic evidence to reveal the ways by which trade policy affects performance at the firm and industry levels. We take this microeconomic approach and investigate the effects on firms brought about by trade liberalization (see also Baier et al., 2019).

Plenty of studies have shown that trade liberalization stimulates firm innovation, productivity and efficiency, while also helping to lower price levels (Saggay, Heshmati, and Dhif, 2007; Mazumder, 2014; Edmond, Midrigan, and Xu, 2015), but there are only few works that examine directly firm-level indicators of market power. This paper takes a firm-level approach to examine how trade liberalization shapes domestic market power using a unique database containing several firm-level indicators, detailed tariff information and agreggate trade flows data for emerging market and developing economies and puts a special focus on sub-Saharan Africa.

We look for microeconomic evidence to answer the following questions. Does trade liberalization is significantly associated with the degree of domestic market power? How is this association across industries? What is the relationship between the level of tariff rates or the size of trade flows with market power? What role play other macro-level factors and structural reforms not directly related to international trade to shape domestic competition?

The results show that opening to international trade is associated with limiting domestic market power. The lower trade tariffs the lower the markups, and the same holds for nontariff trade barriers. Also, we find that firms with higher markups experience a larger reduction in markups after trade liberalization but, in contrast to private firms, the markups of public firms may even increase. At the industry level, lowering tariffs is associated with larger reduction in markups in the tradable sector, and especially in the manufacturing sector. The relationship between lowering trade barriers and declining markups is identified also in estimations using a sample of sub-Saharan African countries and detailed data on tariffs by sector. The results also show that import penetration leads to significant declines in markups but firms that are able to compete in international markets can have an increase in their markups. Finally, we find that there are important complementarities between trade reforms and other structural reforms, consequently reform packages should pay attention to these complementarities to ensure in domestic competition.

The rest of the paper is organized as follows. Section 2 describes the different datasets used. Section 3 outlines the empirical strategies to evaluate the effects on domestic market structures of trade liberalization and trade integration. Section 4 presents the results of the empirical models used. Section 5 reports robustness checks and Section 6 presents the conclusions.

\section{DAtA}

The complete dataset used covers 83 emerging and developing economies over the period 2000-2017. Table 1 presents the list of economies in the sample — which is made mainly of developing countries, including 29 sub-saharan countries, and 8 emerging economies - and a 
summary of data statistics. The sample covered was dictated by the availability of variables at the firm level needed for the estimations.

Firm markups. A critical part of the database consists of firm level information on markups and several firm characteristics obtained from the Orbis database (Orbis Bureau van Dijk; Moody's Analytics). The indicator of market power in domestic markets is the firm's markup constructed, following in De Loecker and Warzynski (2012), as the (log) ratio of the output elasticity of inputs to the expenditure share of those inputs in total sales. Under this approach, assuming common technology within a given industry it is possible to derive an estimating equation to compute markups using standard production firm-level data as in Hall (1986) using the approach of Ackerberg, Caves and Frazier (2006). A detailed explanation of the construction of the markups used in this paper can be found in Cherif et al. (2020) from which the markups are obtained. Since data on quantities of output, capital and variable inputs are not available, the markup estimation uses as approximations to those variables the reported operating revenues, tangible and intangible fixed assets, and the cost of goods sold. The database covers about 400,000 firms. $^{2}$

Firm-level control variables. Following the literature, the models to study markups control for several firm characteristics — obtained from Orbis - that could confound the relation between trade liberalization and firms' market power. Firm size is measured by the (log of) firm assets, which may influence markups due to concentration in the sector, while the leverage ratio controls for firms' debt levels, and firm (log) age is used as indicator of expertise acumulated in the firm. These firm-level control variables are lagged in the estimations to avoid endogeneity. In order to control for industry effects, the 2-digit International Standard Industrial Classification of All Economic Activities (ISIC) is used to construct identificator variables to capture industry effects that do not change over time. In addition to firm-level fixed effects, also the estimations will include industry-year fixed effects to capture trends that may affect specific industries.

Trade liberalization indicators. The following indicators of trade liberalization obtained from the Fraser Institute (see Gwartney et al., 2019) are used in the analysis: in relation to tarifss, the mean tariff score, the mean tariff rate and the overall tariff score, and for other barriers the non-tariff trade barriers score. Specifically, in the estimations the degree of trade liberalization is represented by the mean tariff score. Higher scores, which range from 0 to 10 , indicate greater freedom to trade internationally. In the robustness checks, we also use as alternative indicators of trade liberalization the mean tariff rate, which gives an unweighted mean of tariff rates, and the overall tariff score, which results from a combination of the mean tariff rate, the standard deviation of tariff rates, and indicators of revenues from taxes on international trade.

Trade reform indicator. Based on the Fraser Institute mean tariff score, a trade reform variable is constructed as a dummy variable that takes the value of one when an economy achieves a positive change in the score of at least one standard deviation, and this change is

\footnotetext{
${ }^{2}$ For more details see also the online annex of IMF (2019a).
} 
not undone in the following years. In this way, we identify trade reforms that are not reversed to study the dynamic effects of trade reforms. ${ }^{3}$

Tariff data. The emprirical analysis also includes detailed tariff data at the product level that is mapped to different industries following the concordance principles of Pierce and Schott (2009). These tariff data helps identify the more nuanced effects of lowering import barriers, as there are multiple aspects in which trade policy measures differ across industries. To construct the indicator of tariffs for each sector, the product-level tariff data is compiled and organized according to the 2-digit Harmonized System (HS) of the UNCTAD Trade Analysis Information System (TRAINS), and weighted according to bilateral trade volumes obtained from the UN Commodity Trade database (COMTRADE). Then, using the concordance principles between the HS codes and the industry classification, we construct detailed time series for tariff rates at the industry level for each economy. Detailed data yields additional information on the variation in trade protection levels across different sectors and how they change over time, creating a dynamnic measure of exposure to foreign competition by industry for each economy.

Trade flows. A commonly used indicator of an economy's degree of trade liberalization is the level of trade openness: the sum of exports and imports relative to an economy's GDP. We split this into imports as a percentage of GDP and exports as a percentage of GDP to examine their different effects on markups. Also, an additional indicator of foreign competition used is the import penetration ratio, calculated as the ratio of imports over total domestic demand. These variables are constructed using data from the IMF World Economic Ourtlook database

Other macroeconomic variables. A rich set of economy-level variables is used as control variables, including an indicator of institutional quality from the World Bank; an indicator of economic policy uncertainty; the level of per capita GDP in PPP terms; the contemporaneous growth of GDP, and the inflation rate. These macroeconomic variables are collected from the World Bank World Development Indicators (WDI), the IMF World Economic Outlook (WEO) database, and the Economic Policy Uncertainty Index (EUI) from The Economist Intelligence Unit.

Structural reform indicators. Indicators of different structural reforms are needed to implement the random forest methodology, which will be used to disentangle the relative importance of different structural reforms in shaping competition in domestic markets. For most economies trade liberalization usually takes place in conjunction with a package of structural reforms in fiscal, financial, and real sectors. All these reforms can potentially shape domestic competition, therefore it is important to distinguish the relationship of domestic

\footnotetext{
${ }^{3}$ The construction of the reform indicator follows only a statistical criterion. An alternative approach, the "episodical" approach would determine periods of trade reform based on existing case studies in the literature and announcements or policymakers of major reform efforts. This is, it would not be based on a mechanical criterion but on a qualitative classification of those episodes according to how they are considered in the literature and news. Given the number of economies considered in this paper (83), we find it more appropriate to follow the statistical criteria described above.
} 
market power with changes in the degree of trade liberalization with from relationships with other reforms as well as evaluating their complementarity.

The structural reform indicators are constructed using the IMF Monitoring of Fund Arrangements database (MONA), which contains conditionality and outcomes of all Fundsupported programs since 2002. We focus on structural benchmarks recorded in the MONA database, which are non-quantifiable reform measures that are critical to achieving program goals, assuming that they represent major structural reform episodes. We organize the structural benchmarks obtained from the MONA database into three categories according to their impact on the fiscal, financial, and real sectors as shown in Table 2 (see also Kouamé and Tapsoba, 2018). To construct the indicators of structural reforms that will be used together with the indicator of trade liberalization, we apply the centered-reduced normalization method as in OECD (2008). The normalized reform indexes are defined as follows: Reform $k t=\frac{N_{k t}-N_{t}}{\sigma_{t}}$ where $N_{k t}$ is the total number of successful strucutral reforms in economy $k$ during the last review of the IMF board in year $t ; N_{t}$ is the average number of successful structural reforms for all economies in year $t$; and $\sigma_{t}$ is its standard deviation. In this way we transform structural reform variables into a comparable unit.

\section{EMPIRICAL STRATEGIES}

Different methodologies are used to identify the association between trade liberalization and domestic market power: different versions of panel regressions; models for the dynamic relationship of trade reforms and markups, and a random forest methodology; which is a popular machine learning model to disentangle the effects of different factors and assess their substitutability or complementarity.

\section{A. Regressions}

The first step to identify the relation between trade liberalization and domestic market power is based on the following panel regression set-up:

$$
\begin{aligned}
\text { Markup }_{i, j, k, t}= & \beta_{0}+\beta_{1} \text { Trade Liberalization Indicator }_{k, t-1}+\beta_{2} \text { Markup }_{i, j, k, t-1} \\
& +\beta_{3} C_{k, t-1}+\beta_{4} F_{i, t-1}+\gamma_{i}+\rho_{t}+\varphi_{j, t}+\varepsilon_{i, j, k, t}
\end{aligned}
$$

where Markup is the natural log of the markup as defined above for firm $i$ in industry $j$ in economy $k$ at time $t$. The trade liberalization indicator is the mean tariff score of economy $k$ at time $t-1$ obtained from the Fraser Institute. This indicator is lagged to avoid endogeneity issues. $C$ and $F$ are vectors of economy and firm characteristics; and $\gamma, \rho$, and $\varphi$ are firm, year and industry-year fixed effects, respectively. The indicator of non-tariff trade barriers is also included with a lag among the variables in vector $C$. The fixed effects control for invariant through time characteristics at the firm level, in addition to year effects for each industry. The coefficient of interest is $\beta_{1}$ which is associated with the trade liberalization indicator. If $\beta_{1}$ is negative and significant, a higher mean tariff score - lower tariff barriers-is associated with less market power as shown by lower markups. 
The baseline specification shown above does not allow to assess how the relationship of trade liberalization and domestic market power evolves over time. In order to analyze the dynamics of this relationship it is necessary to look at how markups evolve after episodes of trade reform. As noted above, a trade reform in a given economy is defined as an episode in which the mean tariff score increases by at least one standard deviation compared with the history of the economy and this increase is not reversed afterwards. Thus, in model (1) we substitute the mean tariff score with a reform dummy that takes the value of 1 in the year of the reform and allow for several lags of it.

In model (2), $H$ represents the time periods, from 0 to 5 , for which the lagged relationship of trade reform and domestic market power are evaluated. Examining the significance and magnitude of the sum of the different $\alpha_{h}$ enables us to estimate the cumulative effect of trade reforms.

$$
\begin{aligned}
\operatorname{Markup}_{i, j, k, t}= & \beta_{0}+\sum_{h \in H} \alpha_{h} \text { Trade reform } \\
k, t-h & +\beta_{2} \text { Markup }_{i, j, k, t-1}+\beta_{3} C_{k, t-1} \\
& +\beta_{4} F_{i, t-1}+\gamma_{i}+\rho_{t}+\varphi_{j, t}+\varepsilon_{i, j, k, t}
\end{aligned}
$$

\section{B. Impulse-Responses}

An additional method to evaluate the dynamic effects of trade reforms is to analyze impulse responses using the local projection method (LPM) of Jorda (2005). See Equation (3). In this model, the left-hand side variable is the cumulative change in markup from period $t$ to $t+h$, with $t$ denoting the year and $h$ going from 0 to 5 . The set of variables in the right-hand side includes the trade reform indicator defined above as the impulse variable and a collection of control variables including the vectors of variables $C$ and $F$ defined above, plus one lag of them and the collection fixed effects. The aim is to identify the projected effect of the trade reform indicator in the $h$ years following the reform event. The construction of the trade reform indicator yields an identification strategy of unexpected policy changes as long as it is reasonable to assume that such large changes in the indicator are unrelated to other variables in the model.

$$
\begin{aligned}
& \left.\Delta \text { Markup }_{i, j, k, t+h}-\text { Markup }_{i, j, k, t}\right) \\
& \quad=\alpha+\beta_{h} \text { Trade Reform Indicator }_{k, t}+\sum_{p=0,1} \gamma_{h} C_{k, t-p}+\sum_{p=0,1} \delta_{h} F_{i, t-p}+\gamma_{i} \\
& \quad+\rho_{t}+\varphi_{j, t}+\varepsilon_{i, j, k, t}
\end{aligned}
$$

\section{Complementarity of Different Reforms}

A primer exploration of the complementarity between different structural reforms is done by estimating model (4), where markups are associated by the following variables: the trade liberalization indicator used above; the indexes constructed for structural reforms in other sectors (fiscal, financial and real sectors) based on the MONA database; interactions between 
the trade reform indicator and the indexes for other reforms, and the set of control variables included in the baseline model.

$$
\begin{aligned}
& \text { Markup }_{i, j, k, t}=\beta_{0}+\beta_{1} \text { Trade Lib. Indicator } \text { Int }-1_{1} \\
& +\sum_{j=1,2,3} \beta_{j} \text { Stuctural Reform Index }_{j, k, t} \\
& \begin{array}{l}
+\sum_{l=1,2,3} \beta_{3} \text { Trade Lib. Indicator }_{k, t-1} * \text { Structural Reform Index } \\
\\
\quad+\beta_{4, k, t} \text { Markup }_{i, j, k, t-1}+\beta_{5} C_{k, t-1}+\beta_{6} F_{i, t-1}+\gamma_{i}+\rho_{t}+\varphi_{j, t}+\varepsilon_{i, j, k, t}
\end{array}
\end{aligned}
$$

\section{Random Forest Algorithm}

The random forest algorithm is designed to better identify the effects of a factor when other factors are present. If a reduction in tariffs across industries and over time is correlated with other reforms or policy measures, such as financial liberalization, tax policy changes, or labor market reforms, it is possible that empirical methods could attribute the impact of other structural reforms to trade liberalization. To control for the concurrent reforms it is useful to include various structural reform indices in our regressions. However, this may lead to overfitting when using a standard OLS regression as the only method, especially in the presence of several correlated variables. In addition, an OLS model requires a number of assumptions which may not necessarily apply in the case of structural reforms, for instance, the linearity of the effects estimated.

An alternative method to study the effects of different reforms consists in using the assumption-free decision-tree approach, which is computationally efficient and works well in cases where there are important nonlinearities and interactions. A decision tree uses an if-else logic hierarchically depending on different "features" in order to predict a "response". The random forest algorithm modifies the decision-tree approach by imposing randomness in the selection of both the sample and features to be studied while minimizing the problem of overfitting and lack of generalization of a standard OLS regression. Rather than imposing an overly complex structure, the random forest methodology seeks to improve predictive power by generating numerous decision trees, splitting over a random subset of features - including the trade liberalization indicator, indicators of other reforms and the other variables in the baseline model - and taking an average of all the individual decision tree estimates. By averaging the results, the random forest estimation reduces the variance without increasing bias (see Breiman, 2001).

In our random forest model, the "response" occurs in the markup, the indicator of market power and there is a total of 12 "features" or predictors that may affect the response, including, among others, tariff rates, structural reform indicators, economy-level and firmlevel characteristics. We first use a 50-50 split to partition the whole dataset into the training set and the testing set. The hyper parameters to be determined are the number of regression trees in the forest and the number of features to be considered at each tree node. In general, the more the trees the better the results to be obtained. This parameter is preset at 500, but as it is shown later the error rate converges quickly at around 100 trees. Having tuned the 
number of trees, we find that the lowest error rate is obtained when the number of randomly selected features to be considered is 4 .

For each tree node in the final ensemble of 500 trees, the optimal node-splitting feature selected from a set of 4 features that are picked randomly from the 12 features is used to split the data into two sub-nodes. The criterion for selecting the optimal node-splitting feature is to do it in such a way that the correlation between different trees decreases and thus the average response of multiple regression trees is expected to have lower variance than the individual regression trees. Each tree stops splitting when all the samples in the node have the same response or are locally constant. The predicted value of the response of the variable of interest is the mean prediction of all individual regression trees.

Figure 1 provides a simplified demonstration of the random forest structure. In this figure, we single out one binary decision tree out of the 500 similar decision trees in the random forest. For this tree, the four randomly chosen features for node splitting are trade reform, real sector reform, fiscal reform, and financial reform. The first tree node bifurcates based on the value of the trade reform indicator. If the value does not exceed 0.02 , then the next optimal nodesplitting feature is the real sector reform indicator. For observations whose indicator for real sector reform is equal to or less than 0.78 , this node stops splitting, and we end up with an estimated markup equal to 0.452 . In other words, for a given observation with $0.01(\leqslant 0.02)$ in trade reform indicator and $0.75(\leqslant 0.78)$ in the real sector reform indicator, the fitted value of its markup would be 0.452 . The depth of this tree node is 3 , which is the number displayed in the bracket. We iterate this procedure 500 times and the same number of trees is generated. The predicted markup is thus the mean of markups across the terminal nodes.

Finally, we focus on the ranking of variable importance score to evaluate the importance of the different structural reforms for markup prediction. The importance score measures by how much removing a variable decreases accuracy and vice versa: if accuracy remains the same when one variable is randomly ommited, that variable cannot be considered important. Using this method, the analysis of different reform periods in different economies and the wide variation of outcomes when economies implement seemingly similar packages of structural reforms allows the identification of the relative importance of the different reforms. This method can provide useful information for the design of future reform packages.

\section{Results}

\section{A. Panel Regressions}

To evaluate the relationship of market power and trade tariffs, non-tariff trade barriers and trade flows, several models are estimated. In the preferred regression model, the level of markups (in logs) is a function of the following variables: at the firm level, the (log) of firm assets, the leverage ratio and the age of the firm (all lagged). At the economy level, the indicators of barriers to trade are the mean tariff score and the indicator of non-tariff barriers; the (lagged) indicator of institutional quality captures the environment in which firms operate in terms of institutions and regulations; and to control for the level of development of the economy and the economic context in which firms operate we include the level of per capita 
GDP in PPP terms and the growth of GDP and consumer prices. In addition, the models include fixed effects to control for invariant through time characteristics at the firm level and industry-year fixed effects.

Lower trade barriers are associated with more limited market power. The results across models suggest that the higher the mean tariff score (the lower the tariffs) the lower are markups, and the same holds for non-tariff barriers. A one unit improvement in the mean tariff score is associated with a statistically significant decrease in markups of 0.5 percent. This result is robust to the exclusion of several firm- and economy-level control variables, as shown in columns 1 and 2 of Table 3. The preferred model is shown in column 3.

To examine the potential effects in the results of the inclusion of the lagged dependent variable in our panel data setting, we check the results omitting the lagged markup. Column 4 shows that the omission of the lagged dependent variable does not induce a meaningful change in the estimate corresponding to the mean tariff score and others are very similar. Based on this result, we continue using our prefered model including a lagged markup to capture inertia in the series.

In the literature on markups a low level of inertia is interpreted as a reflection of more limited market power (resulting in more variability of markups over time) while more entrenched market power would allow to maintain more stable levels of markups (see for instance Glen et al., 2003). Following this literature, we corroborated in our data that industries that show more inertia in markups also tend to show the highest markups. ${ }^{4}$

We also examined if there is a significant difference in the effects of trade liberalization on markups for developing and emerging economies. To answer this question the preferred model was estimated including a dummy with value 1 for emerging economies interacted with the lagged mean tariff score. The estimate corresponding to the mean tariff score for the entire sample resulted -0.006 (only slightly different to the -0.005 estimate in the original model) and considering the difference estimated for emerging economies the total estimate for these economies is -0.004 (a difference of 0.002 ). However, the estimated difference for emerging economies is significant only at the 10 percent level of confidence. Thus, while we can say that there is a difference in the relationship of trade liberalization and markups between developing and emerging economies, it turns out to be small and not very significant.

While the baseline equation identifies a significant negative association of trade liberalization and markups, the cost of relying on economy-specific indicators is that we make less use of industry-specific variation. To exploit the differential degree of trade liberalization across industries we replace the trade liberalization indicator used above (the mean tariff score) with industry specific tariff rates constructed with detailed information on product-level tariff rates obtained from IMF (2019b). This particular estimation focuses on sub-Saharan African countries. As shown in Table 4, the coefficient on tariff rates (lagged) is positive and significant, implying that higher tariff rates are associated with stronger market power of

\footnotetext{
${ }^{4}$ An ample comparison of markup levels around the world can be found in Cherif et al. (2020).
} 
firms in domestic markets. More specifically, a 10 percent reduction in tariff rates is associated with a decrease in markups of about 1 percent. This estimate is similar in magnitude and robust across all specifications in Table 4, which show different sets of control variables while maintaining the magnitude and significance of the positive association of markups and tariff rates. The tariff rates used in this estimation are industry specific thus the lower markup associated with tariff reductions could be more precisely ascribed to the introduction of foreign competition at the industry level. This result is consistent with the findings of Navas and Licandro (2011), Arkolakis et al. (2015), and Ahmed and Zaki (2016). ${ }^{5}$

\section{B. Dynamic Effects of Reforms}

The evaluation of the effects of tariffs on domestic competition should consider that those effects do not occur only in one year and market adjustments take time to materialize (see Saggay et al., 2007, for the cumulative effects of trade reforms). To study the dynamic effects of a tariff reform on markups we estimate several versions of model (2). Table 5 shows that after five years markups have been reduced in a statistically significant way by about 4.3 percent following a trade reform, and Figure 2 shows the cumulative decline over time.

An additional way to evaluate the dynamic effects of tariff reforms on markups is provided by the local projections method (LPM), which is used to project, based on previous data, the cumulative response of markups after a reform for different horizons. One regression (as in model 3) is estimated for each horizon or number of years: $h=0, \ldots, 5$. The point estimate and standard error corresponding to the reform indicator from each regression are used to depict the projected response of markups in the years following the reform. Figure 3 shows the estimates obtained and their significance. The cumulative response after five years is a 3.8 percent reduction in markups and is statistically significant at the 1 percent level. This result is similar to the estimated lagged effect of the reform obtained above.

\section{Trade Liberalization and Firm and Sector Characteristics}

The characteristics of firms shape the way trade liberalization is associated with market power. The assessment of these factors is done using variations of model (1). As shown in Table 6, while private firms show a reduction in markups associated with trade liberalization, firms with majority ownership by the government tend to increase their markups. This could be because public firms tend to be more protected and are less susceptible to foreign competition, but the most likely reason we identify in the data is that public firms tend to operate in nontradable sectors: only about 24 percent of public firms are in tradable sectors. Thus, these firms may benefit from increased availability of cheaper inputs and at the same time not facing increased competition. Meanwhile, firms with higher markups see a larger reduction in their markups associated to tariff changes (column 2), indicating that trade liberalization not only promotes competition in general, but also has a stronger association

\footnotetext{
${ }^{5}$ We checked for the potential effect of the inclusion of the lagged dependent variable in the panel data regression and found only a small effect in the estimate of interest (Table 3, column 4).
} 
with higher markups. This helps to reduce market power in sectors with less competition and alleviate markup disparity.

Tariff changes can have differentiated effects in specific sectors (Yang and Hwang, 1999). This hypothesis is explored in the models shown in Table 7, where dummies corresponding to different sectors are interacted with the mean tariff score indicator. The markups in the tradable sector (which includes manufacturing, agricultural, fishing and mining products) are more strongly associated with changes in tariffs, with an additional decline associated with lower tariffs, and this additional decline comes from manufactured products, as shown in columns 1 to 3 . The reduction in the average markups in the manufacturing sector is larger than for economy-wide average markups. On top of the $1 / 2$ percent decline in the average markup, there is a statistically significant additional decrease in manufacturing markups of about 0.8 of a percentage point.

Looking into the sector of information and communications technology (ICT) is of special interest, as it is typically fast growing and highly concentrated. For this sector, more opening to foreign competition, as reflected in an improvement in the mean tariff score, is associated with an additional reduction in average markups of about 2.5 percent, on top of 0.4 percent average reduction observed across all sectors (column 4). This additional effect of liberalization on ICT markups could be related to the relatively high capital intensity in this sector, as opening the imports of capital goods may contribute to more competition in this sector and the reduction of markups of incumbents. Thus, an effective tool to limit market power in the ICT sector is the opening to competition from abroad and of imports equipment and technology. However, concerning head to head competition from firms from abroad, it should be recognized that this will require carefull design and implementation because this sector is heavily reliant on networks (in addition to large infrastructure and asset requirements) that creates a trend toward natural monopolies. In this case, adequate regulation may have an important contribution in addition to efforts to increase competition.

\section{Trade Integration and Market Power}

A useful measure of foreign competition in domestic markets is import penetration, defined as the ratio of imports to total domestic demand-GDP minus exports plus imports. The results of the model estimated are shown in Table 8 , column 2 . The coefficient corresponding to the interaction term is positive and significant suggesting that firms in economies where there is more import penetration have a more marked decline in domestic firms' market power associated with tariff reductions. This is consistent with the findings of Altomonte and Baratieri (2014).

The effect of international competition on market power can also be evaluated by looking into the relationship between the degree of integration to international trade and the level of markups. In the following models, the mean tariff score is substituted with indicators of trade flows. The results show that an increase in trade integration with the rest of the world is associated with a reduction in the average markup (Table 9, column 1). Furthermore, to test for differentiated effects of increases in exports and imports, an additional model is estimated in which the indicator of openness to trade is decomposed into the imports-to-GDP ratio and

the exports-to-GDP ratio. We should expect these two indicators to have opposite signs as 
more openness to imports exerts direct competition to local firms and should help compress markups, while more opportunities to export help expand markets for domestic firms which can reach economies of scale and thus increase profitability. The estimates show the expected signs and are statistically significant (Table 9, column 2). Also, it is interesting to note that the magnitude of the negative estimate for imports is about three times the positive estimate of exports. A higher ratio of imports-to-GDP by 10 percentage points is associated with average markups that are on average 1.2 percent lower, while the same difference in the ratio of exports-to-GDP is associated with an increase in the average markup of 0.4 percent. These results confirm that opening domestic market to foreign competition helps to limit domestic market power but also allows export-oriented firms to increase profitability.

A model with interaction terms between trade liberalization and other structural reforms is useful to explore the potential substitutability and complementarity between structural reforms. According to the results in Table 10, other contemporaneous structural reforms do not seem to have brought about significant reductions in the markup of firms when carried out in isolation. In fact, financial reforms per se seem to help increase markups, most likely by decreasing financial intermadiation costs. However, there are complementarities between trade liberalization and other reforms, as suggested by the negative coefficient associated to the interaction terms: for a given level of tariff rate, the higher the structural reform index the lower the markups. The complementarity is statistically significant for the interaction between trade reforms and real sector reforms, and while the interaction term also shows a negative sign for the financial sector reforms and the fiscal reform they are non-significant. This pattern is consistent with the results of Macedo and Martins (2008) who find a positive spillover of structural reforms on international competitiveness using data for the European Union.

\section{E. Differentiated Effects of Concurrent Structural Reforms}

To better understand the relationship between different structural reforms on market power it is necessary to differentiate the magnitude of their effects. Sub-Saharan Africa is home to most IMF programs, thus the MONA database allows to construct the necessary indexes to track the different structural reforms and study the interplay of different reforms. More specifically, using the random forest algorithm, we can study the relative importance of our main indicator of trade liberalization, the mean tariff score, and other indicators of structural reforms to explain changes in markups. In the regression trees used, every node implies a condition about how to split values in a single feature, where the condition is to provide sufficiently low variance with adequate predictive power. For each tree we can compute how much each feature contributes to decreasing the variance over the trees. The greater the contribution, the higher the variable importance score and the more important the feature is in predicting the response.

Our random forest model achieves good performance soon, this is with a relatively small number of tree nodes. The mean squared error (MSE) estimated stablizes at 0.02 with only about 100 tree nodes (Figure 4) and is relatively similar to that calculated against the test data. The mean squared error shown in the figure is calculated as: 


$$
M S E=\frac{1}{n} \sum_{i=1}^{n}\left(y_{i}-\hat{y}_{i}\right)^{2}
$$

where $n$ is the number of data points, $y_{i}$ represents the observed values, and $\hat{y}_{i}$ stands for the predicted value of the response.

The indicator of interest to be obtained from the model is the ranking of variable importance. The scores of this indicator shown in Figure 5 reveal that trade liberalization (a decrease in tariff barriers that is reflected in an increase in the mean tariff score) has the largest impact on markups, followed by real sector reforms, fiscal reforms, and financial reforms. This result reiterates that trade liberalization is an effective tool to limit market power in domestic markets beyond other reforms.

\section{Robustness Checks}

In order to check the robustness of the results, alternative models are estimated using different definitions of markup and trade liberalization variables, as well as different control variables and additional factors. Table 11 reports the results. In column (1), the markup variable used as dependent variable in the baseline model is substituted with a markup indicator directly calculated from the financial information of each firm: the (log) ratio of operating revenues to the cost of the goods sold. In columns 2 and 3 we use the original markup series as the dependent variable but the indicator of trade liberalization is substituted alternatively with the mean tariff rate (a higher indicator means more trade protection) and the overall tariff score (a higher indicator means lower trade protection) of the Fraser Institute. Finally, in columns 4 and 5, we include the return on assets at the firm level obtained from the Orbis database as an additional variable to control for firm productivity, a factor that could affect markups in the absence of changes in competition, and replace the inflation rate with the index for economic policy uncertainty within the set of macroeconomic control variables. In all cases, the baseline results and conclusions remain robust.

\section{CONCLUSIONS}

This paper studies the relationship between trade liberlization and domestic market power in emerging market eonomies and developing countries and offers a particular focus on subSaharan Africa. Different models show that there is a significant negative relationship of trade liberalization and integration to international trade with domestic market power using a large firm-level panel dataset covering about 400,000 firms in the period 2000-2017.

There is substantive evidence suggesting that lower trade barriers and increased trade integration are effective tools for policies aimed at limiting market power in domestic markets. This conclusion is obtained using fixed effects regression models to estimate the behavior of domestic markups after changes in various indicators of trade liberalization, including economy-level trade liberalization indicators, tariff rates for specific industries and aggregate trade flows. To explore the economic channels underlying such impact, we also 
allow the trade liberalization indicator to interact with characteristics of firms, industries and macroeconomic variables.

Trade liberalization is associated with a decline of markups and this relationship is robust across different specifications. By unraveling adjustment processes in firms' dynamics in response to changes in trade policies, the full effect of trade liberalization materializes in the medium term. This is the conclusion from two different methods suggesting that trade reforms lead to significant declines in markups of about 4 percent in the five year period after the reforms.

The relationship between trade integration with the rest of the world and domestic market power differs across sectors. As expected, markups in industries that participate in the tradable sector are more sensitive to changes in tariffs, in particular manufacturing industries. Also, industries in the ICT sector shows important reductions in markups following tariff reductions. The market power of firms in sectors with more import penetration have a stronger response to tariff changes, and indicators of trade integration with the rest of the world are associated with increased domestic competition and declining of markups.

A very interesting result is that increased flows of imports tend to reduce markups while increased exports are associated with an increase in markups, with the magnitude of the relationship with imports being about three times that of exports. This is, increased trade integration not only helps to limit market power in domestic markets but it also allows export oriented firms to be more profitable thanks to the expansion of their markets and achieving economies of scale.

The substitutability and complementarity of reforms concerning their effects on domestic competition was also studied. There are reinforcing effects between trade liberalization and other reforms and the stronger complementarity is between trade and real sector reforms, followed by reforms in the financial and fiscal sectors but the latter are not significant statistically.

The random forest algorithm approach suggests that trade liberalization has the largest impact on markups, followed by real sector reforms, fiscal reforms, and financial reforms. This result corroborates once again that trade liberalization is a very effective tool to conttol market power in domestic markets.

Despite the raise of trade protectionism attitudes seen worldwide that threaten to roll back decades of liberalization efforts, this paper provides robust empirical evidence suggesting that trade liberalization is an effective policy option to limit the raise of market power and its implications (see De Loecker, Eeckhout and Unger, 2018). 


\section{REFERENCES}

Ackerberg, D., K. Caves, and G. Frazer, 2006, Structural Identification of Production Functions, mimeo, UCLA.

Ahmed, A. and C. Zaki, 2016, Trade Liberalization and Market Competition: Evidence from Egypt Firm-level Data. European Trade Study Group working Paper.

Altomonte, C., and A. Barattieri. 2015. "Endogenous Markups, International Trade, and the Product Mix," Journal of Industry, Competition and Trade 15(3):205-221.

Amiti, M. and J. Konings. 2007. "Trade liberalization, intermediate inputs, and productivity: Evidence from Indonesia." American Economic Review 97(5): 611-1638.

Arkolakis, C., A. Costinot, D. Donaldson and A. Rodríguez-Clare. 2019. "The Elusive ProCompetitive Effects of Trade." The Review of Economic Studies 86(1): 46-80.

Baier, S. L., V. Yotov Yoto, and T. Zylkin. 2019. “On the Widely Differing Effects of Free Trade Agreements: Lessons from Twenty Years of Trade Integration." Journal of International Economics 116: 206-26.

Bloom, N., M. Draca, and J. Van Reenen. 2016. “Trade Induced Technical Change? The Impact of Chinese Imports on Innovation, IT and Productivity." Review of Economic Studies 83(1): 87-117.

Boler, E. A., A. Moxnes, and K. H. Ulltveit-Moe. 2015. "R\&D, International Sourcing and the Joint Impact on Firm Performance. American Economic Review 105(12): 3663703.

Bordon, A. R., K. Shirono, and C. Ebeke. 2016. "When Do Structural Reforms Work? On the Role of the Business Cycle and Macroeconomic Policies." IMF Working Paper, 16/62. International Monetary Fund: Washington DC.

Brandt, L., J. Van Biesebroeck, L. Wang, and Y. F. Zhang. 2017. "WTO Accession and Performance of Chinese Manufacturing Firms." American Economic Review 107: 2784-820.

Breiman, L., 2001, Random Forests, Machine Learning, 45:5-32.

Bustos, P. 2011. "Trade Liberalization, Exports and Technology Upgrading: Evidence on the Impact of Mercosur on Argentinean Firms. American Economic Review 101(1): 304340 .

Chen, N., J. Imbs, and A. Scott. 2009. “The Dynamics of Trade and Competition." Journal of International Economics 77(1): 50-62.

Cherif, R., Dhungana. S., Fang, X., Gonzalez-Garcia, J., Yang, Y., Yenice, M., and Yoon, JE. 2020. "Competition, Competitiveness and Growth in Sub-Saharan Africa", IMF Working Paper, 20/30. International Monetary Fund: Washington DC. 
Christiansen L., M. Schindler, and T. Tressel, 2009, Growth and Structural Reforms: A New Assessment. IMF Working Paper 09/284. International Monetary Fund: Washington D.C.

Dabla-Norris, E., G. Ho, and A. Kyobe, 2016, Structural Reforms and Productivity Growth in Emerging Market and Developing Economies. IMF Working Paper, 16/15. International Monetary Fund: Washington D.C.

De Loecker, J. and F. Warzynski. 2012. "Markups and Firm-Level Export Status." American Economic Review, 102(6): 2437-2471.

De Loecker, J. and J. Van Biesebroeck. 2016. "Effect of International Competition of Firm Productivity and Market Power.” NBER working paper 21994.

De Loecker, J., J. Eeckhout, and G. Unger. 2018. “The Rise of Market Power and the Macroeconomic Implications," NBER Working Paper 24768, National Bureau of Economic Research, Cambridge, MA.

Edwards, S. 1998. “Openness, Productivity, and Growth: What Do We Really Know?" Economic Journal 108: 383-98.

ElFayoumi K., A. Ndoye, S. Nadeem, and G. Auclair, 2018, Structural Reforms and Labor Reallocation: A Cross-Country Analysis. IMF working paper, 18/64. International Monetary Fund: Washington D.C.

Fernandes, A. 2007. "Trade Policy, Trade Volumes and Plant-level Productivity in Colombian Manufacturing Industries." Journal of International Economics 71: 5172 .

Glen, J., Lee, K. and Singh, A. 2003. "Corporate Profitability and the Dynamics of Competition in Emerging Markets: A Time Series Analysis". The Economic Journal, 113(491): 465-484.

Gwartney, J., Robert L., Hall, J., and Murphy, R. 2019. Economic Freedom of the World: 2019 Annual Report. Fraser Institute: Vancouver B.C.

Goldberg, P., A. Khandelwal, N. Pavcnik, and P. Topalova. 2010. "Imported Intermediate Inputs and Domestic Product Growth: Evidence from India." Quarterly Journal of Economics 125: 1727-67.

Hall, R.E., 1986. "Market Structure and Macroeconomic Fluctuations.” Brookings Papers on Economic Activity 2: 285-322.

IMF. 2019a. Regional Economic Outlook: Sub-Saharan Africa, October, International Monetary Fund: Washingdon D.C.

IMF. 2019b. Regional Economic Outlook: Sub-Saharan Africa, April, Chapter 3 "Is the African Continental Free Trade Area a Game Changer for the Continent?" International Monetary Fund: Washingdon D.C.

Jorda, O. 2005. "Estimation and Inference of Impulse Responses by Local Projections," American Economic Review 95(1): 161-182 
Kasahara, H., and J. Rodriguez. 2008. "Does the Use of Imported Intermediates Increase Productivity? Plant-level Evidence.” Journal of Development Economics 87: 106-18.

Khandelwal, A. K. and P. Topalova, 2011, "Trade liberalization and firm productivity: The case of India." Review of Economics and Statistics 93(3): 995-1009.

Konings, J., P. Van Cayseele, and F. Warzynski. 2001. "The Dynamics of Industrial MarkUps in Two Small Open Economies: Does National Competition Policy Matter?." International Journal of Industrial Organization, 19(5): 841-859.

Kouamé, W. and Tapsoba, S. 2018."Structural Reforms and Firms' Productivity: Evidence from Developing Countries." IMF Working Paper 18/63.

Lileeva, A. and D. Trefler. 2010. "Improved Access to Foreign Markets Raises Plant-Level Productivity...For Some Plants.” Quarterly Journal of Economics 125(3): 1051-1099.

Macedo, J.B. and J.O. Martins, 2008, Growth, Reform Indicators and Policy Complementarities, The Economics of Transition, The European Bank for Reconstruction and Development, Volume 16(2), Pages 141-164, April.

Mazumder, S. 2014. "The Price-marginal Cost Markup and Its Determinants in U.S. Manufacturing." Macroeconomic Dynamics, 18(4): 783-811.

Navas A. and O. Licandro. 2011. "Trade Liberalization, Competition and Growth.” The B.E. Journal of Macroeconomics 11(1): 1-28.

OECD, 2008, Handbook on Constructing Composite Indicators: Methodology and User Guide. OECD: Paris.

Pierce, J. and P. Schott. 2009. “A Concordance Between Ten-Digit U.S. Harmonized System Codes and SIC/NAICS Product Classes and Industries.” NBER working paper 15548.

Rodriguez, F. and Rodrik, D. 2001. "Trade Policy and Economic Growth: A Skeptic's Guide to the Cross-National Evidence," NBER Macroeconomics Annual 2000, 15.

Saggay, A., A. Heshmati and M.A. Dhif. 2007. "Effects of Trade Liberalization on Domestic Prices: Some Evidence from Tunisian Manufacturing." International Review of Economics, 54: 148.

Spilimbergo, A., A. Prati, and J. D. Ostry. 2009. "Structural Reforms and Economic Performance in Advanced and Developing Countries.” IMF Working Paper, 16/268. International Monetary Fund: Washington D.C.

Teshima, K., 2009, Import Competition and Innovation at the Plant Level: Evidence from Mexico. Mimeo.

UNCTAD. 2009. "The Relationship between Competition, Competitiveness and Development," Issues Note No. 6-09, April.

Yang, Y. and M. Hwang, 1999, Effects of Trade Liberalization on Domestic Prices: The Evidence From Korea, 1983-1995. Mimeo. Department of Economics California State University. 


\section{TABLES}

Table 1. Economies Coverage and Summary of Data Statistics

\section{A. Economies Coverage}

\begin{tabular}{|c|c|c|c|c|c|}
\hline \multicolumn{2}{|c|}{$\begin{array}{c}\text { Sub-Saharan African } \\
\text { countries }\end{array}$} & \multicolumn{4}{|c|}{ Other emerging and developing economies } \\
\hline Angola & Mauritius & Albania & Ecuador & Lebanon & Sudan \\
\hline Benin & Mozambique & Algeria & Egypt & Macedonia & Taiwan Province of China \\
\hline Botswana & Namibia & Armenia & El Salvador & Mexico & Thailand \\
\hline Burkina Faso & Nigeria & Azerbaijan & Georgia & Mongolia & Tunisia \\
\hline Cameroon & Rwanda & Bangladesh & Guatemala & Morocco & Turkey \\
\hline Cape Verde & Senegal & Belarus & Honduras & Myanmar & Uzbekistan \\
\hline Cote d'Ivoire & Seychelles & Bhutan & Indonesia & Nepal & Venezuela \\
\hline Ethiopia & South Africa & Bolivia & Iraq & Nicaragua & Vietnam \\
\hline Gabon & Swaziland & Bosnia and Herzegovina & Iran & Papua New Guinea & Yemen \\
\hline Gambia & Togo & Brazil & Jamaica & Paraguay & \\
\hline Ghana & Uganda & Bulgaria & Jordan & Peru & \\
\hline Kenya & Tanzania & Cambodia & Kazakhstan & Moldova & \\
\hline Liberia & Zambia & Colombia & Kosovo & Romania & \\
\hline Malawi & Zimbabwe & Costa Rica & Kyrgyzstan & Serbia & \\
\hline Mali & & Dominican Republic & Laos & Sri Lanka & \\
\hline
\end{tabular}

B. Summary Statistics

\begin{tabular}{lrrrrr}
\hline & & \multicolumn{3}{c}{ Standard } \\
Variable & Observations & Mean & deviation & Min & Max \\
\hline Markup & $1,058,307$ & 0.185 & 0.290 & -5.000 & 2.884 \\
Mean Tariff Score & $1,125,091$ & 7.858 & 0.437 & 3.960 & 9.540 \\
Non-tariff trade barriers & $1,125,086$ & 5.211 & 0.525 & 2.500 & 7.523 \\
Institutional quality & $1,135,963$ & 3.731 & 0.246 & 1.133 & 5.500 \\
Assets & $1,135,963$ & 13.904 & 2.161 & 1.386 & 33.567 \\
Leverage & $1,135,963$ & 0.066 & 0.225 & 0.000 & 178.416 \\
Age & $1,135,963$ & 2.348 & 0.827 & 0.000 & 6.910 \\
Log of per capita GDP & 732 & 8.878 & 0.795 & 6.503 & 10.707 \\
GDP growth & 732 & 0.042 & 0.029 & -0.033 & 0.088 \\
Inflation & 732 & 0.061 & 0.039 & -0.009 & 0.130 \\
\hline
\end{tabular}

Source: Author's calculations. 
Table 2. Construction of Structural Reform Indices

\begin{tabular}{lll}
\hline Sector & & \multicolumn{1}{c}{ Definition } \\
\hline Fiscal & 1. & Revenue measures, excluding trade policy; \\
& 2. & Revenue administration, including customs; \\
& 3. & Expenditure measures, including arrears clearance; \\
4. & Combined expenditure and revenue measures; \\
5. & Debt management; \\
6. & Expenditure auditing, accounting, and financial controls; \\
7. & Fiscal transparency (publication, parliamentary oversight); \\
8. & Budget preparation (e.g., submission or approval); \\
9. & Inter-governmental relations; \\
& 10. & PRSP development and implementation; \\
1. & Anti-corruption legislation/policy; \\
12. & Pensions reforms; \\
13. & Other social sector reforms (e.g., social safety nets, health and education). \\
\hline Financial & 1. & Financial sector legal reforms, regulation, and supervision; \\
2. & Restructuring and privatization of financial institutions; \\
3. & Central bank operations and reforms; \\
4. & Central bank auditing, transparency, and financial controls. \\
\hline Real & Private sector legal and regulatory environment reform (non-financial \\
& sector); \\
2. & Natural resource and agricultural policies (excluding public enterprises \\
& and pricing) \\
3. & Civil service and public employment reforms, and wages; \\
4. & Public enterprise pricing and subsidies; \\
5. & Privatization, public enterprise reform and restructuring, other than \\
& pricing; \\
6. & Price controls and marketing restrictions; \\
7. & Labor markets, excluding public sector employment.
\end{tabular}
Source: Monitoring of Fund Arrangements database, IMF. 
Table 3: Markups and Trade Barriers-EMEDEV

\begin{tabular}{|c|c|c|c|c|}
\hline & \multicolumn{4}{|c|}{ Log of markup } \\
\hline & EMEDEV & EMEDEV & EMEDEV & EMEDEV \\
\hline & (1) & $(2)$ & (3) & (4) \\
\hline Mean tariff score & $\begin{array}{c}-0.005^{* * *} \\
(0.001)\end{array}$ & $\begin{array}{c}-0.004 * * * \\
(0.001)\end{array}$ & $\begin{array}{c}-0.005^{* * *} \\
(0.001)\end{array}$ & $\begin{array}{c}-0.006^{* * *} \\
(0.001)\end{array}$ \\
\hline Lagged markup & $\begin{array}{c}0.208 * * * \\
(0.003)\end{array}$ & $\begin{array}{c}0.198^{* * * *} \\
(0.004)\end{array}$ & $\begin{array}{c}0.198 * * * \\
(0.004)\end{array}$ & \\
\hline Non-tariff trade barriers & $\begin{array}{l}-0.001 \\
(0.001)\end{array}$ & $\begin{array}{c}-0.001^{* *} \\
(0.001)\end{array}$ & $\begin{array}{c}-0.001 \\
(0.001)\end{array}$ & $\begin{array}{c}-0.001 * * \\
(0.001)\end{array}$ \\
\hline Institutional quality & $\begin{array}{c}-0.014 * * * \\
(0.001)\end{array}$ & $\begin{array}{c}-0.011 * * * \\
(0.001)\end{array}$ & $\begin{array}{c}-0.013 * * * \\
(0.001)\end{array}$ & $\begin{array}{c}-0.015^{* * *} \\
(0.002)\end{array}$ \\
\hline Log of assets & & $\begin{array}{c}-0.002 * * \\
(0.001)\end{array}$ & $\begin{array}{c}-0.001^{* *} \\
(0.001)\end{array}$ & $\begin{array}{c}0.002^{*} \\
(0.001)\end{array}$ \\
\hline Leverage & & $\begin{array}{c}0.002 * * * \\
(0.001)\end{array}$ & $\begin{array}{c}0.002 * * * \\
(0.001)\end{array}$ & $\begin{array}{c}-0.000 \\
(0.000)\end{array}$ \\
\hline Firm age & & $\begin{array}{c}0.006 * * * \\
(0.001)\end{array}$ & $\begin{array}{c}0.006^{* * *} \\
(0.001)\end{array}$ & $\begin{array}{c}0.014 * * * \\
(0.002)\end{array}$ \\
\hline Log of per capita GDP & & & $\begin{array}{c}-0.039^{* * *} \\
(0.012)\end{array}$ & $\begin{array}{c}-0.048^{* * *} \\
(0.014)\end{array}$ \\
\hline GDP growth & & & $\begin{array}{c}-0.067 * * * \\
(0.013)\end{array}$ & $\begin{array}{c}-0.085^{* * *} \\
(0.014)\end{array}$ \\
\hline Inflation & & & $\begin{array}{c}-0.015 \\
(0.013) \\
\end{array}$ & $\begin{array}{c}-0.014 \\
(0.015) \\
\end{array}$ \\
\hline Observations & $1,358,556$ & $1,058,307$ & $1,058,307$ & $1,118,110$ \\
\hline Number of firms & 435,767 & 366,548 & 366,548 & 393,538 \\
\hline R-squared & 0.056 & 0.050 & 0.050 & 0.011 \\
\hline Firm fixed effects & Yes & Yes & Yes & Yes \\
\hline Year fixed effects & Yes & Yes & Yes & Yes \\
\hline Industry-year fixed effects & Yes & Yes & Yes & Yes \\
\hline
\end{tabular}

Source: Author's calculations.

Note: Standard errors clustered at the firm level. *** $\mathrm{p}<0.01, * * \mathrm{p}<0.05, * \mathrm{p}<0.1$. 
Table 4: Markups and Trade Barriers-SSA

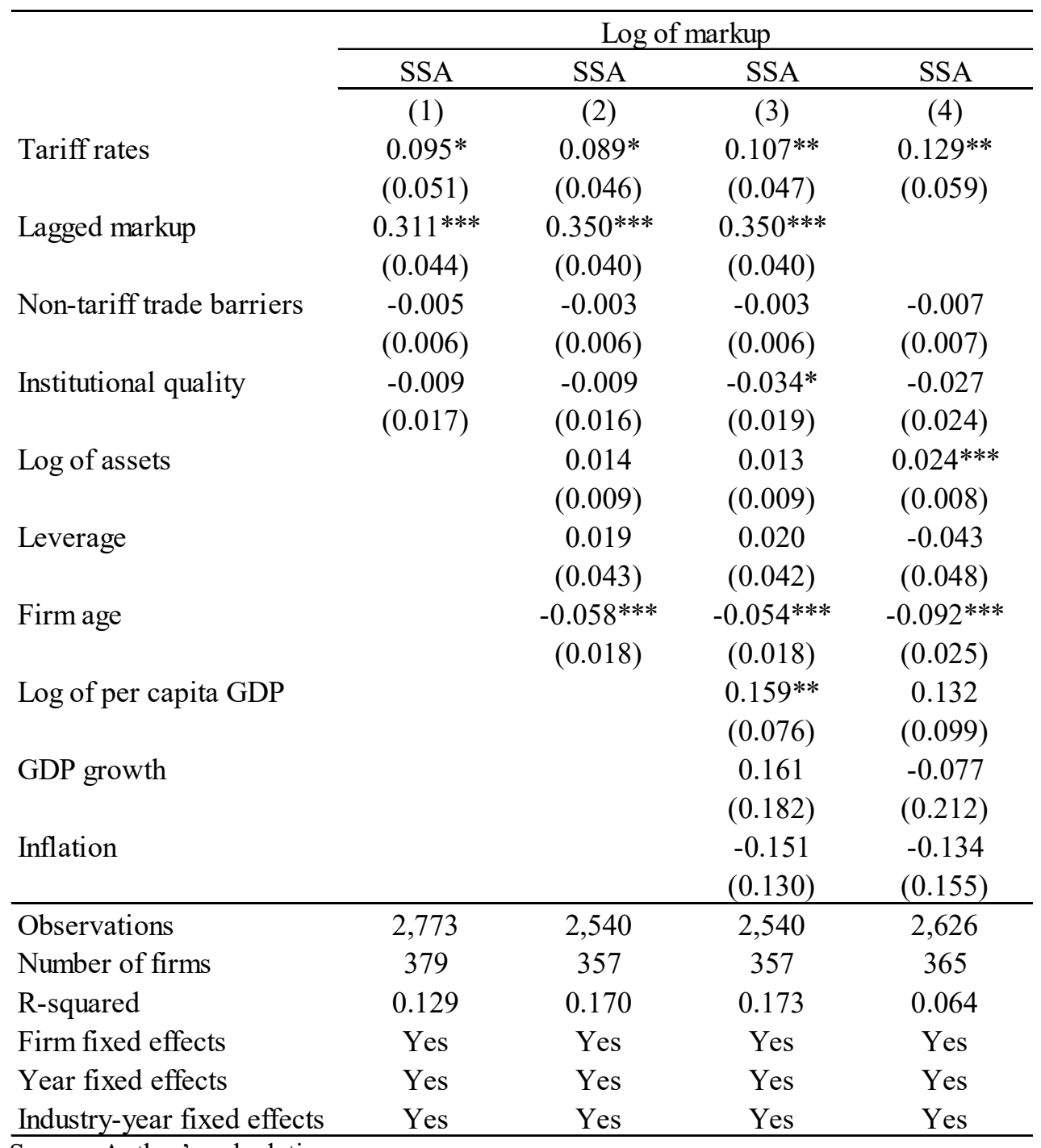

Source: Author's calculations.

Note: Standard errors clustered at the firm level. ${ }^{* *} \mathrm{p}<0.01,{ }^{* *} \mathrm{p}<0.05,{ }^{*} \mathrm{p}<0.1$. 
Table 5: Effects of Tariff Reform on Markups

\begin{tabular}{|c|c|c|c|c|c|c|}
\hline & \multicolumn{6}{|c|}{ Log of markup } \\
\hline & (1) & (2) & (3) & (4) & (5) & (6) \\
\hline Reform & $\begin{array}{c}-0.018^{* * *} \\
(0.002)\end{array}$ & $\begin{array}{c}-0.021^{* * *} \\
(0.002)\end{array}$ & $\begin{array}{c}-0.022^{* * * *} \\
(0.002)\end{array}$ & $\begin{array}{c}-0.021^{* * *} \\
(0.002)\end{array}$ & $\begin{array}{c}-0.017^{* * *} \\
(0.002)\end{array}$ & $\begin{array}{c}-0.010^{* * *} \\
(0.002)\end{array}$ \\
\hline Reform lag 1 & & $\begin{array}{c}0.008 * * * \\
(0.001)\end{array}$ & $\begin{array}{c}0.007 * * * \\
(0.001)\end{array}$ & $\begin{array}{c}0.006^{* * * *} \\
(0.001)\end{array}$ & $\begin{array}{c}0.010^{* * *} \\
(0.001)\end{array}$ & $\begin{array}{c}0.013 * * * \\
(0.001)\end{array}$ \\
\hline Reform lag 2 & & & $\begin{array}{c}-0.003 * * * \\
(0.001)\end{array}$ & $\begin{array}{c}-0.004 * * * \\
(0.001)\end{array}$ & $\begin{array}{c}-0.006^{* * *} \\
(0.001)\end{array}$ & $\begin{array}{c}-0.002 * * \\
(0.001)\end{array}$ \\
\hline Reform lag 3 & & & & $\begin{array}{c}-0.006^{* * *} \\
(0.001)\end{array}$ & $\begin{array}{c}-0.009 * * * \\
(0.001)\end{array}$ & $\begin{array}{c}-0.012 * * * \\
(0.001)\end{array}$ \\
\hline Reform lag 4 & & & & & $\begin{array}{c}-0.018 * * * \\
(0.001)\end{array}$ & $\begin{array}{c}-0.022 * * * \\
(0.001)\end{array}$ \\
\hline Reform lag 5 & & & & & & $\begin{array}{c}-0.014 * * * \\
(0.001)\end{array}$ \\
\hline Lagged markup & $\begin{array}{c}0.198 * * * \\
(0.004)\end{array}$ & $\begin{array}{c}0.198 * * * \\
(0.004)\end{array}$ & $\begin{array}{c}0.197 * * * \\
(0.004)\end{array}$ & $\begin{array}{c}0.196 * * * \\
(0.004)\end{array}$ & $\begin{array}{c}0.188 * * * \\
(0.004)\end{array}$ & $\begin{array}{c}0.179 * * * \\
(0.004)\end{array}$ \\
\hline Non-tariff trade barriers & $\begin{array}{c}-0.004^{* * *} \\
(0.001)\end{array}$ & $\begin{array}{c}-0.003 * * * \\
(0.001)\end{array}$ & $\begin{array}{c}-0.003 * * * \\
(0.001)\end{array}$ & $\begin{array}{c}-0.005^{* * *} \\
(0.001)\end{array}$ & $\begin{array}{c}-0.005^{* * *} \\
(0.001)\end{array}$ & $\begin{array}{c}-0.001 \\
(0.001)\end{array}$ \\
\hline Institutional quality & $\begin{array}{c}0.002 \\
(0.003)\end{array}$ & $\begin{array}{c}0.002 \\
(0.003)\end{array}$ & $\begin{array}{c}0.003 \\
(0.003)\end{array}$ & $\begin{array}{c}-0.002 \\
(0.003)\end{array}$ & $\begin{array}{c}-0.012 * * * \\
(0.003)\end{array}$ & $\begin{array}{c}-0.028 * * * \\
(0.004)\end{array}$ \\
\hline Log of assets & $\begin{array}{c}-0.003^{* * *} \\
(0.001)\end{array}$ & $\begin{array}{c}-0.003^{* * *} \\
(0.001)\end{array}$ & $\begin{array}{c}-0.003 * * * \\
(0.001)\end{array}$ & $\begin{array}{c}-0.003 * * * \\
(0.001)\end{array}$ & $\begin{array}{c}-0.003^{* * *} \\
(0.001)\end{array}$ & $\begin{array}{c}-0.003 * * * \\
(0.001)\end{array}$ \\
\hline Leverage & $\begin{array}{l}0.005 * * \\
(0.002)\end{array}$ & $\begin{array}{l}0.005 * * \\
(0.002)\end{array}$ & $\begin{array}{l}0.005 * * \\
(0.002)\end{array}$ & $\begin{array}{l}0.005 * * \\
(0.002)\end{array}$ & $\begin{array}{c}0.004 * \\
(0.002)\end{array}$ & $\begin{array}{l}0.005 * * \\
(0.002)\end{array}$ \\
\hline Firm age & $\begin{array}{c}0.005^{* * *} \\
(0.002)\end{array}$ & $\begin{array}{c}0.006 * * * \\
(0.002)\end{array}$ & $\begin{array}{c}0.006^{* * *} \\
(0.002)\end{array}$ & $\begin{array}{c}0.005 * * * \\
(0.002)\end{array}$ & $\begin{array}{c}0.006^{* * *} \\
(0.002)\end{array}$ & $\begin{array}{c}0.006^{* * *} \\
(0.002)\end{array}$ \\
\hline Log of per capita GDP & $\begin{array}{c}-0.199 * * * \\
(0.020)\end{array}$ & $\begin{array}{c}-0.232^{* * *} \\
(0.021)\end{array}$ & $\begin{array}{c}-0.242^{* * *} \\
(0.021)\end{array}$ & $\begin{array}{c}-0.226^{* * *} \\
(0.023)\end{array}$ & $\begin{array}{c}-0.179^{* * *} \\
(0.023)\end{array}$ & $\begin{array}{c}-0.083 * * * \\
(0.027)\end{array}$ \\
\hline GDP growth & $\begin{array}{c}-0.030 \\
(0.019)\end{array}$ & $\begin{array}{c}0.009 \\
(0.020)\end{array}$ & $\begin{array}{c}0.007 \\
(0.020)\end{array}$ & $\begin{array}{c}0.016 \\
(0.020)\end{array}$ & $\begin{array}{c}-0.013 \\
(0.020)\end{array}$ & $\begin{array}{c}0.015 \\
(0.020)\end{array}$ \\
\hline Inflation & $\begin{array}{c}-0.087^{* * *} \\
(0.017)\end{array}$ & $\begin{array}{c}-0.123^{* * *} \\
(0.017) \\
\end{array}$ & $\begin{array}{c}-0.118^{* * *} \\
(0.017) \\
\end{array}$ & $\begin{array}{c}-0.107^{* * *} \\
(0.018) \\
\end{array}$ & $\begin{array}{c}-0.082^{* * *} \\
(0.018) \\
\end{array}$ & $\begin{array}{c}0.046^{*} \\
(0.024) \\
\end{array}$ \\
\hline Observations & 906,727 & 906,727 & 906,331 & 904,988 & 890,155 & 871,975 \\
\hline Number of firms & 318,462 & 318,462 & 318,429 & 318,323 & 317,313 & 316,219 \\
\hline R-squared & 0.051 & 0.051 & 0.051 & 0.051 & 0.047 & 0.043 \\
\hline Sum of effects & & $-0.013 * * *$ & $-0.018 * * *$ & $-0.025 * * *$ & $-0.040 * * *$ & $-0.047 * * *$ \\
\hline Prob $>$ F & & 0.000 & 0.000 & 0.000 & 0.000 & 0.000 \\
\hline Firm fixed effects & Yes & Yes & Yes & Yes & Yes & Yes \\
\hline Year fixed effects & Yes & Yes & Yes & Yes & Yes & Yes \\
\hline Industry-year fixed effects & Yes & Yes & Yes & Yes & Yes & Yes \\
\hline
\end{tabular}

Source: Author's calculations.

Note: Standard errors clustered at the firm level. *** $\mathrm{p}<0.01, * * \mathrm{p}<0.05,{ }^{*} \mathrm{p}<0.1$. 
Table 6. Effects of International Trade on Markups by Firm Characteristics

\begin{tabular}{|c|c|c|}
\hline & \multicolumn{2}{|c|}{ Log of markup } \\
\hline & $(1)$ & (2) \\
\hline \multirow[t]{2}{*}{ Mean tariff score } & $-0.004 * * *$ & $-0.003 * *$ \\
\hline & $(0.001)$ & $(0.001)$ \\
\hline \multirow[t]{2}{*}{ Mean tariff score * public dummy } & $0.056 * * *$ & \\
\hline & $(0.019)$ & \\
\hline \multirow[t]{2}{*}{ Mean tariff score $*$ lagged markup } & & $-0.039 * * *$ \\
\hline & & $(0.004)$ \\
\hline \multirow[t]{2}{*}{ Lagged markup } & $0.220 * * *$ & $0.567 * * *$ \\
\hline & $(0.005)$ & $(0.031)$ \\
\hline \multirow[t]{2}{*}{ Non-tariff trade barriers } & 0.001 & 0.000 \\
\hline & $(0.001)$ & $(0.001)$ \\
\hline \multirow[t]{2}{*}{ Institutional quality } & $-0.008 * * *$ & $-0.008 * * *$ \\
\hline & $(0.002)$ & $(0.002)$ \\
\hline \multirow[t]{2}{*}{ Log of assets } & -0.000 & $-0.003 * * *$ \\
\hline & $(0.001)$ & $(0.001)$ \\
\hline \multirow[t]{2}{*}{ Leverage } & $0.002 * * *$ & $0.002 * * *$ \\
\hline & $(0.001)$ & $(0.001)$ \\
\hline \multirow[t]{2}{*}{ Firm age } & 0.003 & $0.011^{* * *}$ \\
\hline & $(0.002)$ & $(0.002)$ \\
\hline \multirow[t]{2}{*}{ Log of per capita GDP } & -0.022 & -0.012 \\
\hline & $(0.013)$ & $(0.013)$ \\
\hline \multirow[t]{2}{*}{ GDP growth } & 0.024 & $-0.033 * *$ \\
\hline & $(0.015)$ & $(0.014)$ \\
\hline \multirow[t]{2}{*}{ Inflation } & 0.008 & 0.002 \\
\hline & $(0.018)$ & $(0.016)$ \\
\hline Observations & 671,692 & 722,509 \\
\hline Number of firms & 231,083 & 262,660 \\
\hline R-squared & 0.063 & 0.077 \\
\hline Firm fixed effects & Yes & Yes \\
\hline Year fixed effects & Yes & Yes \\
\hline Industry-year fixed effects & Yes & Yes \\
\hline
\end{tabular}


Table 7: Effects of International Trade on Markups by Sector Characteristics

\begin{tabular}{|c|c|c|c|c|}
\hline & \multicolumn{4}{|c|}{ Log of markup } \\
\hline & $(1)$ & $(2)$ & (3) & (4) \\
\hline Mean tariff score & $\begin{array}{c}-0.004 * * * \\
(0.001)\end{array}$ & $\begin{array}{c}-0.004^{* * *} \\
(0.001)\end{array}$ & $\begin{array}{c}-0.005^{* * *} \\
(0.001)\end{array}$ & $\begin{array}{c}-0.004 * * * \\
(0.001)\end{array}$ \\
\hline Mean tariff score $*$ tradable & $\begin{array}{c}-0.008^{* * *} \\
(0.001)\end{array}$ & & & \\
\hline Mean tariff score * manufacturing & & $\begin{array}{c}-0.008^{* * *} \\
(0.001)\end{array}$ & & \\
\hline Mean tariff score * other tradable & & & $\begin{array}{l}-0.006 \\
(0.004)\end{array}$ & \\
\hline Mean tariff score * ICT & & & & $\begin{array}{c}-0.025^{* * *} \\
(0.007)\end{array}$ \\
\hline Lagged markup & $\begin{array}{c}0.196^{* * *} \\
(0.004)\end{array}$ & $\begin{array}{c}0.196^{* * *} \\
(0.004)\end{array}$ & $\begin{array}{c}0.196^{* * *} \\
(0.004)\end{array}$ & $\begin{array}{c}0.196^{* * *} \\
(0.004)\end{array}$ \\
\hline Non-tariff trade barriers & $\begin{array}{c}-0.001 * * \\
(0.001)\end{array}$ & $\begin{array}{c}-0.001 * * \\
(0.001)\end{array}$ & $\begin{array}{l}-0.001 * \\
(0.001)\end{array}$ & $\begin{array}{c}-0.001 * * \\
(0.001)\end{array}$ \\
\hline Institutional quality & $\begin{array}{c}-0.010 * * * \\
(0.002)\end{array}$ & $\begin{array}{c}-0.010^{* * *} \\
(0.002)\end{array}$ & $\begin{array}{c}-0.011 * * * \\
(0.002)\end{array}$ & $\begin{array}{c}-0.011 * * * \\
(0.002)\end{array}$ \\
\hline Log of assets & $\begin{array}{c}-0.002^{* *} \\
(0.001)\end{array}$ & $\begin{array}{c}-0.002^{* *} \\
(0.001)\end{array}$ & $\begin{array}{c}-0.002^{* *} \\
(0.001)\end{array}$ & $\begin{array}{c}-0.002^{* *} \\
(0.001)\end{array}$ \\
\hline Leverage & $\begin{array}{c}0.002 * * * \\
(0.001)\end{array}$ & $\begin{array}{c}0.002 * * * \\
(0.001)\end{array}$ & $\begin{array}{c}0.002 * * * \\
(0.001)\end{array}$ & $\begin{array}{c}0.002^{* * *} \\
(0.001)\end{array}$ \\
\hline Firm age & $\begin{array}{c}0.006^{* * *} \\
(0.001)\end{array}$ & $\begin{array}{c}0.006^{* * * *} \\
(0.001)\end{array}$ & $\begin{array}{c}0.006 * * * \\
(0.001)\end{array}$ & $\begin{array}{c}0.006^{* * *} \\
(0.001)\end{array}$ \\
\hline Log of per capita GDP & $\begin{array}{c}-0.039^{* * *} \\
(0.012)\end{array}$ & $\begin{array}{c}-0.040 * * * \\
(0.012)\end{array}$ & $\begin{array}{c}-0.046^{* * *} \\
(0.012)\end{array}$ & $\begin{array}{c}-0.045 * * * \\
(0.012)\end{array}$ \\
\hline GDP growth & $\begin{array}{c}-0.057 * * * \\
(0.013)\end{array}$ & $\begin{array}{c}-0.058^{* * *} \\
(0.013)\end{array}$ & $\begin{array}{c}-0.068^{* * *} \\
(0.013)\end{array}$ & $\begin{array}{c}-0.066^{* * *} \\
(0.013)\end{array}$ \\
\hline Inflation & $\begin{array}{c}-0.009 \\
(0.014) \\
\end{array}$ & $\begin{array}{c}-0.010 \\
(0.014) \\
\end{array}$ & $\begin{array}{c}-0.015 \\
(0.014) \\
\end{array}$ & $\begin{array}{l}-0.015 \\
(0.014) \\
\end{array}$ \\
\hline Observations & $1,049,782$ & $1,049,782$ & $1,049,782$ & $1,049,782$ \\
\hline Number of firms & 365,813 & 365,813 & 365,813 & 365,813 \\
\hline R-squared & 0.049 & 0.049 & 0.049 & 0.049 \\
\hline Firm fixed effects & Yes & Yes & Yes & Yes \\
\hline Year fixed effects & Yes & Yes & Yes & Yes \\
\hline Industry-year fixed effects & Yes & Yes & Yes & Yes \\
\hline
\end{tabular}

Source: Author's calculations.

Note: Standard errors clustered at the firm level. ${ }^{* * *} \mathrm{p}<0.01,{ }^{* *} \mathrm{p}<0.05,{ }^{*} \mathrm{p}<0.1$. 
Table 8: Effects of International Trade on Markups by Economy Characteristics

\begin{tabular}{|c|c|c|}
\hline & \multicolumn{2}{|c|}{ Log of markup } \\
\hline & (1) & $(2)$ \\
\hline \multirow[t]{2}{*}{ Mean tariff score } & $-0.005 * * *$ & 0.001 \\
\hline & $(0.001)$ & $(0.001)$ \\
\hline \multirow[t]{2}{*}{ Mean tariff score * import penetration } & & $-0.011 * * *$ \\
\hline & & $(0.001)$ \\
\hline \multirow[t]{2}{*}{ Lagged markup } & $0.198 * * *$ & $0.198 * * *$ \\
\hline & $(0.004)$ & $(0.004)$ \\
\hline \multirow[t]{2}{*}{ Non-tariff trade barriers } & -0.001 & $-0.002 * * *$ \\
\hline & $(0.001)$ & $(0.001)$ \\
\hline \multirow[t]{2}{*}{ Institutional quality } & $-0.013 * * *$ & $-0.012 * * *$ \\
\hline & $(0.001)$ & $(0.001)$ \\
\hline \multirow[t]{2}{*}{ Log of assets } & $-0.001 * *$ & $-0.002 * *$ \\
\hline & $(0.001)$ & $(0.001)$ \\
\hline \multirow[t]{2}{*}{ Leverage } & $0.002 * * *$ & $0.002 * * *$ \\
\hline & $(0.001)$ & $(0.001)$ \\
\hline \multirow[t]{2}{*}{ Firm age } & $0.006^{* * *}$ & $0.006 * * *$ \\
\hline & $(0.001)$ & $(0.001)$ \\
\hline \multirow[t]{2}{*}{ Log of per capita GDP } & $-0.039 * * *$ & -0.007 \\
\hline & $(0.012)$ & $(0.013)$ \\
\hline \multirow[t]{2}{*}{ GDP growth } & $-0.067 * * *$ & $-0.044 * * *$ \\
\hline & $(0.013)$ & $(0.013)$ \\
\hline \multirow[t]{2}{*}{ Inflation } & -0.015 & $-0.027 * *$ \\
\hline & $(0.013)$ & $(0.013)$ \\
\hline Observations & $1,058,307$ & $1,058,307$ \\
\hline Number of firms & 366,548 & 366,548 \\
\hline R-squared & 0.050 & 0.050 \\
\hline Firm fixed effects & Yes & Yes \\
\hline Year fixed effects & Yes & Yes \\
\hline Industry-year fixed effects & Yes & Yes \\
\hline
\end{tabular}

Source: Author's calculations.

Note: Standard errors clustered at the firm level. ${ }^{* * *} \mathrm{p}<0.01,{ }^{* *} \mathrm{p}<0.05,{ }^{*} \mathrm{p}<0.1$. 
Table 9: Effects of Trade Openness on Markups

\begin{tabular}{|c|c|c|}
\hline \multirow[b]{3}{*}{ Trade openness } & \multicolumn{2}{|c|}{ Log of markup } \\
\hline & (1) & (2) \\
\hline & $\begin{array}{c}-0.001^{* * *} \\
(0.000)\end{array}$ & \\
\hline Import/GDP & & $\begin{array}{c}-0.137 * * * \\
(0.009)\end{array}$ \\
\hline Export/GDP & & $\begin{array}{c}0.061^{* * *} \\
(0.014)\end{array}$ \\
\hline Lagged markup & $\begin{array}{c}0.198 * * * \\
(0.004)\end{array}$ & $\begin{array}{c}0.198 * * * \\
(0.004)\end{array}$ \\
\hline Non-tariff trade barriers & $\begin{array}{c}-0.002^{* * * *} \\
(0.001)\end{array}$ & $\begin{array}{c}-0.003 * * * \\
(0.001)\end{array}$ \\
\hline Institutional quality & $\begin{array}{c}-0.005^{* * *} \\
(0.002)\end{array}$ & $\begin{array}{c}-0.003 * * \\
(0.002)\end{array}$ \\
\hline Log of assets & $\begin{array}{c}-0.002^{* *} \\
(0.001)\end{array}$ & $\begin{array}{c}-0.001 * * \\
(0.001)\end{array}$ \\
\hline Leverage & $\begin{array}{c}0.002^{* * *} \\
(0.001)\end{array}$ & $\begin{array}{c}0.002^{* * *} \\
(0.001)\end{array}$ \\
\hline Firm age & $\begin{array}{c}0.007 * * * \\
(0.001)\end{array}$ & $\begin{array}{c}0.006^{* * * *} \\
(0.001)\end{array}$ \\
\hline Log of per capita GDP & $\begin{array}{l}0.029^{* *} \\
(0.013)\end{array}$ & $\begin{array}{c}0.002 \\
(0.013)\end{array}$ \\
\hline GDP growth & $\begin{array}{l}-0.013 \\
(0.013)\end{array}$ & $\begin{array}{l}-0.019 \\
(0.013)\end{array}$ \\
\hline Inflation & $\begin{array}{c}-0.030^{* *} \\
(0.013)\end{array}$ & $\begin{array}{c}0.069^{* * * *} \\
(0.015)\end{array}$ \\
\hline Observations & $1,058,319$ & $1,058,319$ \\
\hline Number of firms & 366,553 & 366,553 \\
\hline R-squared & 0.050 & 0.050 \\
\hline Firm fixed effects & Yes & Yes \\
\hline Year fixed effects & Yes & Yes \\
\hline Industry-year fixed effects & Yes & Yes \\
\hline
\end{tabular}

Source: Author's calculations.

Note: Standard errors clustered at the firm level. ${ }^{* * *} \mathrm{p}<0.01,{ }^{* *} \mathrm{p}<0.05,{ }^{*} \mathrm{p}<0.1$. 
Table 10. Complementary Effects of Structural Reforms

\begin{tabular}{|c|c|c|c|}
\hline & \multicolumn{3}{|c|}{ Log of markup } \\
\hline & (1) & (2) & (3) \\
\hline Tariff rates & $0.130^{* *}$ & $0.127 * *$ & $0.145^{* *}$ \\
\hline & $(0.056)$ & $(0.061)$ & $(0.062)$ \\
\hline Financial reform & $\begin{array}{l}0.004 * \\
(0.002)\end{array}$ & & \\
\hline Fiscal reform & & $\begin{array}{c}0.003 \\
(0.003)\end{array}$ & \\
\hline Real sector reform & & & $\begin{array}{c}0.002 \\
(0.002)\end{array}$ \\
\hline Tariff rates * financial reform & $\begin{array}{l}-0.015 \\
(0.013)\end{array}$ & & \\
\hline Tariff rates * fiscal reform & & $\begin{array}{l}-0.012 \\
(0.016)\end{array}$ & \\
\hline Tariff rates * real sector reform & & & $\begin{array}{l}-0.016^{*} \\
(0.009)\end{array}$ \\
\hline Lagged markup & $\begin{array}{c}0.350^{* * *} \\
(0.040)\end{array}$ & $\begin{array}{c}0.351^{* * *} \\
(0.040)\end{array}$ & $\begin{array}{c}0.351^{* * *} \\
(0.040)\end{array}$ \\
\hline Non-tariff trade barriers & $\begin{array}{l}-0.009 \\
(0.006)\end{array}$ & $\begin{array}{l}-0.008 \\
(0.006)\end{array}$ & $\begin{array}{c}-0.008 \\
(0.006)\end{array}$ \\
\hline Institutional quality & $\begin{array}{l}0.016^{*} \\
(0.008)\end{array}$ & $\begin{array}{c}0.016^{*} \\
(0.008)\end{array}$ & $\begin{array}{l}0.016^{*} \\
(0.009)\end{array}$ \\
\hline Log of assets & $\begin{array}{c}0.017 \\
(0.043)\end{array}$ & $\begin{array}{c}0.017 \\
(0.043)\end{array}$ & $\begin{array}{c}0.015 \\
(0.042)\end{array}$ \\
\hline Leverage & $\begin{array}{c}-0.055^{* * *} \\
(0.018)\end{array}$ & $\begin{array}{c}-0.054 * * * \\
(0.018)\end{array}$ & $\begin{array}{c}-0.054^{* * *} \\
(0.018)\end{array}$ \\
\hline Firm age & $\begin{array}{c}-0.044^{* *} \\
(0.021)\end{array}$ & $\begin{array}{c}-0.042^{* *} \\
(0.021)\end{array}$ & $\begin{array}{l}-0.040^{*} \\
(0.021)\end{array}$ \\
\hline Log of per capita GDP & $\begin{array}{l}0.185^{* *} \\
(0.082)\end{array}$ & $\begin{array}{l}0.171 * * \\
(0.080)\end{array}$ & $\begin{array}{l}0.174 * * \\
(0.079)\end{array}$ \\
\hline GDP growth & $\begin{array}{c}0.162 \\
(0.181)\end{array}$ & $\begin{array}{c}0.144 \\
(0.182)\end{array}$ & $\begin{array}{c}0.154 \\
(0.184)\end{array}$ \\
\hline Inflation & $\begin{array}{l}-0.141 \\
(0.132) \\
\end{array}$ & $\begin{array}{l}-0.129 \\
(0.132) \\
\end{array}$ & $\begin{array}{l}-0.159 \\
(0.132) \\
\end{array}$ \\
\hline Observations & 2,537 & 2,537 & 2,537 \\
\hline Number of firms & 357 & 357 & 357 \\
\hline R-squared & 0.178 & 0.177 & 0.178 \\
\hline Firm fixed effects & Yes & Yes & Yes \\
\hline Year fixed effects & Yes & Yes & Yes \\
\hline Industry-year fixed effects & Yes & Yes & Yes \\
\hline
\end{tabular}

Source: Author's calculations.

Note: Standard errors clustered at the firm level. ${ }^{* * *} \mathrm{p}<0.01,{ }^{* *} \mathrm{p}<0.05,{ }^{*} \mathrm{p}<0.1$. 
Table 11. Robustness checks

\begin{tabular}{|c|c|c|c|c|c|}
\hline \multirow[b]{3}{*}{ Mean tariff score } & \multicolumn{5}{|c|}{ Log of markup } \\
\hline & (1) & (2) & (3) & (4) & (5) \\
\hline & $\begin{array}{c}-0.005^{* * *} \\
(0.001)\end{array}$ & & & $\begin{array}{c}-0.007 * * * \\
(0.001)\end{array}$ & $\begin{array}{c}-0.005^{* * *} \\
(0.001)\end{array}$ \\
\hline Mean tariff rate & & $\begin{array}{c}0.212 * * * \\
(0.015)\end{array}$ & & & \\
\hline Overall tariff score & & & $\begin{array}{c}-0.010^{* * *} \\
(0.001)\end{array}$ & & \\
\hline Lagged markup & $\begin{array}{c}0.138^{* * *} \\
(0.004)\end{array}$ & $\begin{array}{l}0.196^{* * *} \\
(0.004)\end{array}$ & $\begin{array}{l}0.196^{* * * *} \\
(0.004)\end{array}$ & $\begin{array}{l}0.211^{* * *} \\
(0.004)\end{array}$ & $\begin{array}{l}0.198^{* * * *} \\
(0.004)\end{array}$ \\
\hline Non-tariff trade barriers & $\begin{array}{c}-0.002^{* * * *} \\
(0.001)\end{array}$ & $\begin{array}{c}-0.002 * * * \\
(0.001)\end{array}$ & $\begin{array}{c}-0.002^{* * *} \\
(0.001)\end{array}$ & $\begin{array}{c}0.001 \\
(0.001)\end{array}$ & $\begin{array}{l}-0.001 \\
(0.001)\end{array}$ \\
\hline Institutional quality & $\begin{array}{c}-0.009^{* * * *} \\
(0.002)\end{array}$ & $\begin{array}{c}-0.004 * * * \\
(0.002)\end{array}$ & $\begin{array}{c}-0.005^{* * * *} \\
(0.002)\end{array}$ & $\begin{array}{c}-0.011 * * * \\
(0.001)\end{array}$ & $\begin{array}{c}-0.013^{* * * *} \\
(0.002)\end{array}$ \\
\hline Log of assets & $\begin{array}{c}-0.011^{* * * *} \\
(0.001)\end{array}$ & $\begin{array}{l}-0.001 * \\
(0.001)\end{array}$ & $\begin{array}{l}-0.001 * \\
(0.001)\end{array}$ & $\begin{array}{c}-0.002 * * * \\
(0.001)\end{array}$ & $\begin{array}{c}-0.001^{* *} \\
(0.001)\end{array}$ \\
\hline Leverage & $\begin{array}{c}0.004 \\
(0.002)\end{array}$ & $\begin{array}{c}0.002 * * * \\
(0.001)\end{array}$ & $\begin{array}{c}0.002 * * * \\
(0.001)\end{array}$ & $\begin{array}{c}0.003 * * * \\
(0.001)\end{array}$ & $\begin{array}{c}0.002 * * * \\
(0.001)\end{array}$ \\
\hline Firm age & $\begin{array}{c}0.007^{* * *} \\
(0.002)\end{array}$ & $\begin{array}{c}0.006^{* * *} \\
(0.001)\end{array}$ & $\begin{array}{c}0.007 * * * \\
(0.001)\end{array}$ & $\begin{array}{c}0.005^{* * *} \\
(0.001)\end{array}$ & $\begin{array}{c}0.006^{* * * *} \\
(0.001)\end{array}$ \\
\hline Return on assets & & & & $\begin{array}{l}-0.003 \\
(0.002)\end{array}$ & \\
\hline Log of per capita GDP & $\begin{array}{c}-0.052 * * * \\
(0.013)\end{array}$ & $\begin{array}{l}-0.015 \\
(0.012)\end{array}$ & $\begin{array}{l}-0.007 \\
(0.012)\end{array}$ & $\begin{array}{c}-0.034 * * * \\
(0.011)\end{array}$ & $\begin{array}{c}-0.040^{* * *} \\
(0.012)\end{array}$ \\
\hline GDP growth & $\begin{array}{c}-0.297 * * * \\
(0.015)\end{array}$ & $\begin{array}{l}-0.014 \\
(0.013)\end{array}$ & $\begin{array}{l}-0.020 \\
(0.013)\end{array}$ & $\begin{array}{c}0.005 \\
(0.013)\end{array}$ & $\begin{array}{c}-0.068^{* * *} \\
(0.013)\end{array}$ \\
\hline Inflation & $\begin{array}{l}-0.012 \\
(0.015)\end{array}$ & $\begin{array}{c}0.013 \\
(0.014)\end{array}$ & $\begin{array}{l}-0.011 \\
(0.013)\end{array}$ & $\begin{array}{l}-0.001 \\
(0.013)\end{array}$ & \\
\hline $\begin{array}{l}\text { Economic policy } \\
\text { uncertainty index }\end{array}$ & & & & & $\begin{array}{l}-0.001 \\
(0.002) \\
\end{array}$ \\
\hline Observations & $1,206,379$ & $1,049,794$ & $1,049,794$ & $1,048,806$ & $1,058,025$ \\
\hline Number of firms & 433,261 & 365,818 & 365,818 & 363,856 & 366,387 \\
\hline R-squared & 0.029 & 0.050 & 0.050 & 0.055 & 0.050 \\
\hline Firm fixed effects & Yes & Yes & Yes & Yes & Yes \\
\hline Year fixed effects & Yes & Yes & Yes & Yes & Yes \\
\hline Industry-year fixed effects & Yes & Yes & Yes & Yes & Yes \\
\hline
\end{tabular}

Source: Author's calculations.

Note: Standard errors clustered at the firm level. $* * * \mathrm{p}<0.01,{ }^{* *} \mathrm{p}<0.05,{ }^{*} \mathrm{p}<0.1$. 


\section{Figures}

Figure 1. Random Forest Tree for Markup Prediction

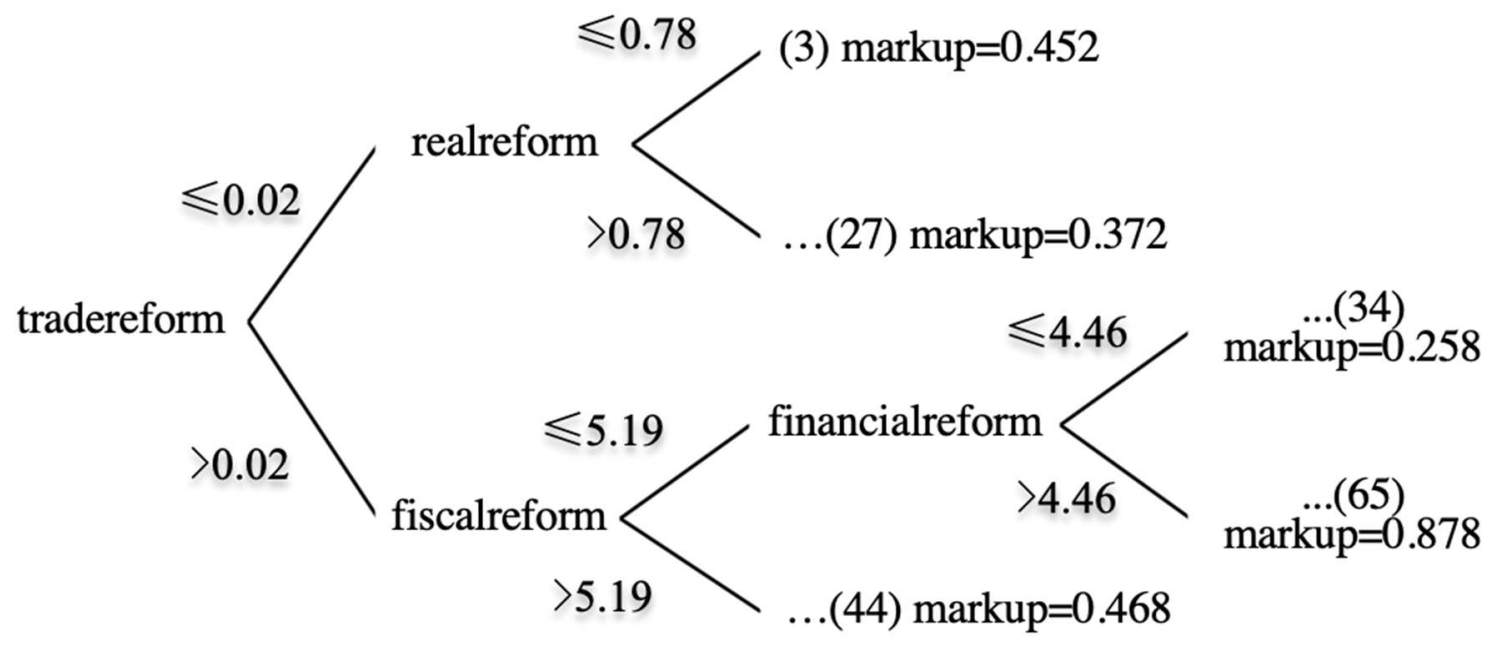

Source: Author's calculations.

Figure 2: Cumulative Lagged Effects of Tariff Reform on Markups

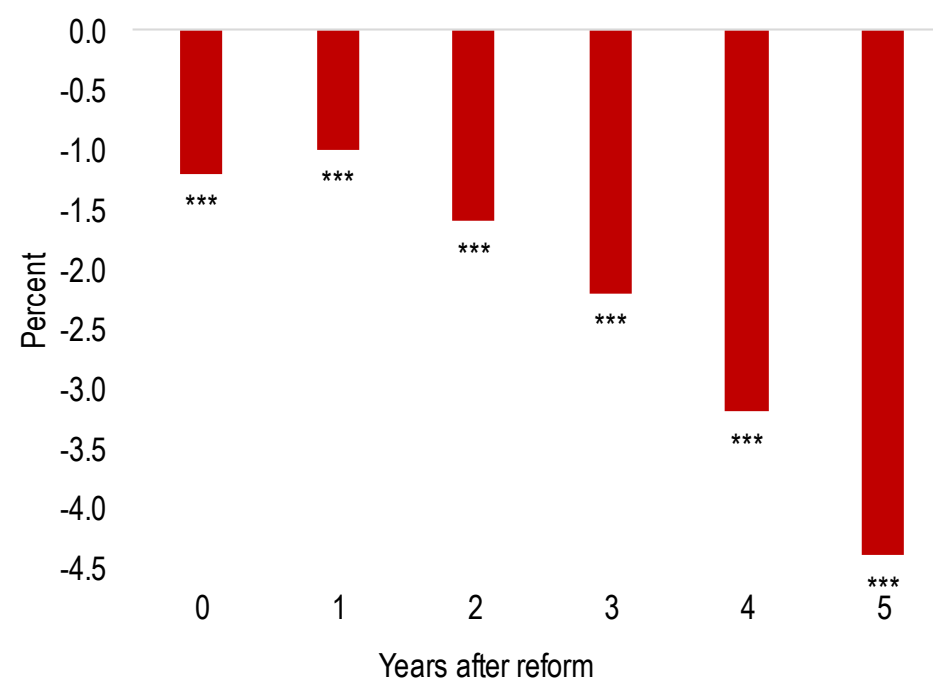

Source: IMF Staff calculations.

Note: Bars show the cumulative effect on markups. ${ }^{* \star}$ denotes statistical significance at 0.01 . 
Figure 3: Cumulative Projected Effects of Tariff Reform on Markups

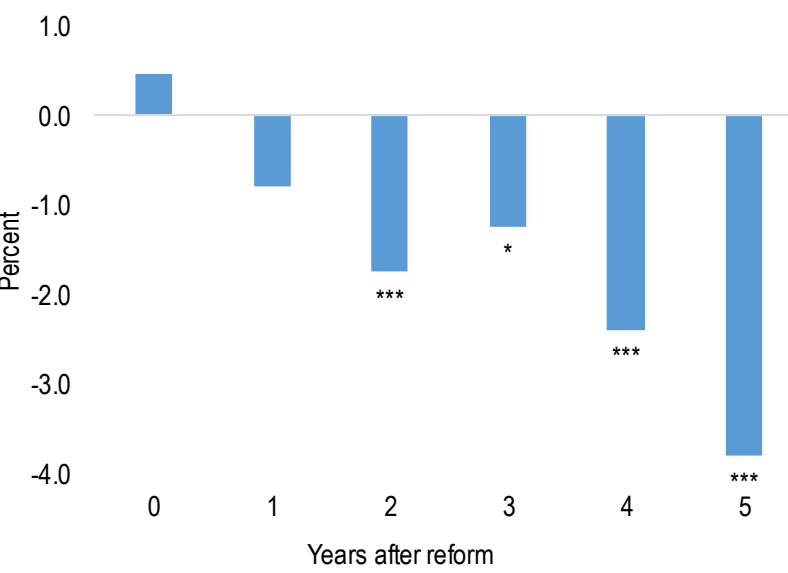

Source: IMF Staff calculations.

Note: Bars show the projected cumulative effect on markups. ${ }^{*}$ and ${ }^{* *}$ denote statistical significance at the 10 and 1 percent levels, respectively.

Figure 4. Mean Squared Error of Random Forest Model

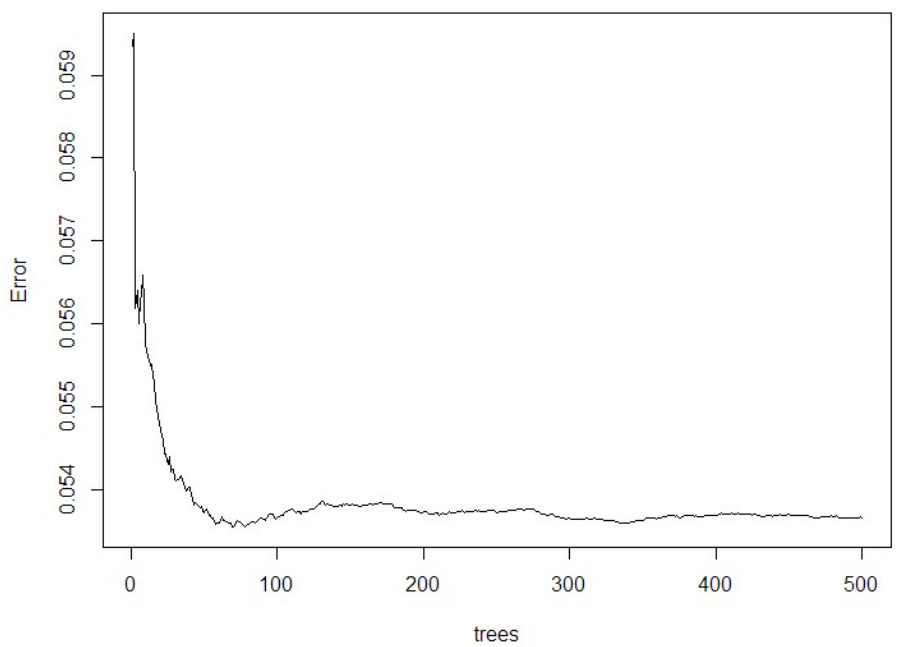

Figure 5. Variable Importance Plot of Random Forest Model

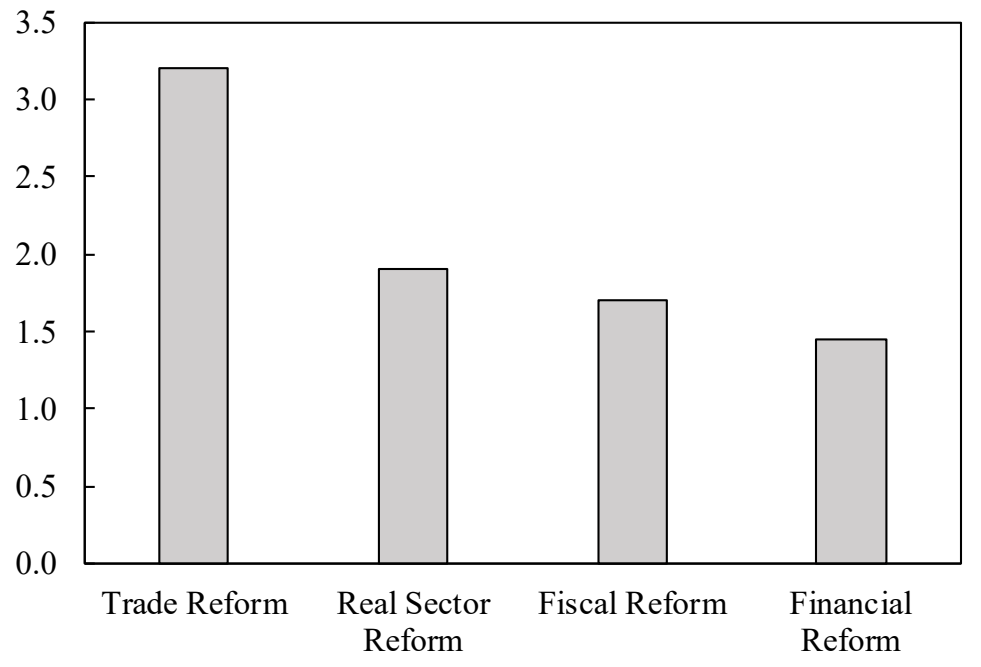

